\title{
UM METÓDICO À BRASILEIRA: A ESCRITA DA HISTÓRIA DE AFONSO DE TAUNAY'
}

\author{
Karina Anhezini \\ Professora do Depto. de História da Universidade Estadual do \\ Centro-Oeste do Paraná - Unicentro.
}

\begin{abstract}
Resumo
Inserido na perspectiva da história da historiografia, o presente artigo busca compreender como se escrevia a história no Brasil nas primeiras décadas do século XX. Para tanto, historiaram-se os procedimentos que fundamentaram a escrita da história de Afonso de Escragnolle Taunay entre 1911 e 1939. Concluiu-se que Taunay foi um metódico à brasileira, pois soube combinar sua leitura da historiografia francesa com o desenvolvimento da produção historiográfica no Brasil.
\end{abstract}

\section{Palavras-chaves}

Escrita da história $\bullet$ verdade moderna $\bullet$ Capistrano de Abreu.

\section{Abstract}

Inserted in the perspective of the historiography, the present article looks for to understand as it was written the history in Brazil in the first decades of the century XX. For so much, it was historied the procedures that based the writing of the History of Afonso de Escragnolle Taunay between 1911 and 1939. It was ended that Taunay was a methodical one in the Brazilian style, because he knew how to combine his reading of the French historiography with the development of the historiography production in Brazil.

\section{Keywords}

Writing of history $\bullet$ modern truth $\bullet$ Capistrano de Abreu.

\footnotetext{
${ }^{1}$ Este artigo é parte do primeiro capítulo da tese intitulada Um metódico à brasileira: A história da historiografia de Afonso de Taunay (1911-1939) defendida em 2006 na Unesp-Franca, sob orientação da prof $\mathrm{f}^{\mathrm{a}} \mathrm{r}^{\mathrm{a}}$ Teresa Maria Malatian. A pesquisa obteve fomento da Capes e da Fundação de Amparo à Pesquisa do Estado de São Paulo - Fapesp.
} 


\section{Os princípios gerais da moderna crítica histórica²}

Foi nesse local [colina situada entre os rios Tamanduateí e Anhangabaú] que padre Manuel de Paiva, superior da nova missão, celebrou, a 25 de janeiro de 1554, a famosa missa evocadora da conversão do Apóstolo das Gentes, ato inicial da existência do pequenino arraial de São Paulo do Campo de Piratininga, vila em 1560 e cidade em 1711. [...] Ergueu-se o pequenino e tosco Colégio inaciano e, em torno desta cellula mater da magnífica metrópole hodierna, agruparamse as choças de alguns brancos e suas progênies mamelucas. ${ }^{3}$

Cena descrita em muitos livros de História e lembrada durante as comemorações dos 450 anos da cidade de São Paulo (2004), essa imagem tornou-se conhecida por meio das diversas obras escritas por Afonso de Taunay e pelos esforços empreendidos por esse autor para transformar o Museu Paulista em um museu dedicado a contar a história do Brasil e, principalmente, a história de São Paulo. ${ }^{4}$

${ }^{2}$ TAUNAY, Afonso de E. Os princípios gerais da moderna crítica histórica. RIHGSP, v. XVI, p. 323-344, 1914.

${ }^{3}$ TAUNAY, Afonso de E. História da cidade de São Paulo. Brasília: Senado Federal, Conselho Editorial, 2004, p. 24 e 26. (Essa obra, cuja primeira edição foi publicada em 1954 pela editora Melhoramentos, em comemoração ao quarto centenário da cidade de São Paulo, é o resultado de uma síntese realizada por Taunay de quase vinte volumes já publicados a respeito da história de São Paulo.) Lofego apresenta um rol das obras publicadas por ocasião das comemorações do IV Centenário; cf. LOFEGO, Silvio Luiz. IV centenário da cidade de São Paulo: uma cidade entre o passado e o futuro. São Paulo: Annablume, 2004, p. 160-162.

${ }^{4}$ A respeito do Museu Paulista e da atuação de Afonso de Taunay nesse museu, cf. ELIAS, Maria José. Museu Paulista: memória e história. Tese de doutorado, História, Faculdade de Filosofia, Letras e Ciências Humanas, Universidade de São Paulo, 1996; ALCÂNTARA, Aureli Alves de. Taunay e a iconografia cafeeira: discurso e recurso. 2000. (Trabalho de conclusão do curso de especialização em Museologia). Museu de Arqueologia e Etnologia - Universidade de São Paulo; OLIVEIRA, Gilberto Habib. O espólio Bernardelli no Museu Paulista e o pensamento museológico de Affonso de Escragnolle Taunay: estudos teórico-metodológicos em Museologia e a historicidade do fenômeno museal. 2000. (Trabalho de conclusão do curso de especialização em Museologia). Museu de Arqueologia e Etnologia - Universidade de São Paulo; ALVES, Ana Maria de Alencar. O Ipiranga apropriado: ciência, política e poder: o Museu Paulista, 1893-1922. São Paulo: Humanitas/FFLCH/USP, 2001; MAKINO, Myoko. A construção da identidade nacional: Afonso de E. Taunay e a decoração do Museu Paulista (1917-1937). Tese de doutorado, História, Faculdade de Filosofia, Letras e Ciências Humanas, Universidade de São Paulo, 2003; MATTOS, Cláudia Valladão de. Da palavra à imagem: sobre o programa decorativo de Affonso Taunay para o Museu Paulista. Anais do Museu Paulista. São Paulo, v. 6/7, n. 7, p. 123-148, 2003; OLIVEIRA, Cecília Helena de Salles. Museu Paulista: espaço de evocação do passado e reflexão sobre a história. Anais do Museu Paulista: História e cultura material. Nova série, vol. 
Taunay pesquisou diversos assuntos relativos à história do Brasil. Embora, dentre historiadores e eruditos das mais variadas áreas, as Bandeiras paulistas e a história do café sejam os estudos mais conhecidos, sua obra é composta por um romance histórico a respeito da invasão holandesa no Brasil, por textos que historiam a Missão Artística Francesa de 1816, bem como por estudos linguísticos a respeito das lacunas dos dicionários portugueses que versavam sobre a língua portuguesa no Brasil. Entretanto, foi sobre a pesquisa da expansão territorial brasileira que o autor mais se debruçou. Foi à escrita da história daquilo que considerava a "conquista do Brasil pelos brasileiros"5 que Taunay dedicou sua vida. Ocupou-se em pesquisar o papel dos sertanistas da capitania de São Paulo na exploração e ocupação do território brasileiro, dedicando-se, especialmente, ao estudo de aspectos variados da história de São Paulo. ${ }^{6}$

A descrição de uma missa rezada no colégio construído em São Paulo do Campo de Piratininga acompanhou a trajetória de Afonso de Taunay. Ele publicou, entre 1915 e 1954, diversas obras a respeito da história desta cidade, local onde iniciou o ofício que o tornaria conhecido como um dos principais historiadores das primeiras décadas do século XX. ${ }^{7}$

10/11,p. 105-126, 2002-2003; BREFE, Ana Cláudia Fonseca. Museu Paulista: Affonso de Taunay e a memória nacional, 1917-1945. São Paulo: Unesp; Museu Paulista, 2005.

${ }^{5}$ TAUNAY, Afonso de E. Um grande bandeirante: Bartolomeu Paes de Abreu (1674 - 1738). Exploração do Paraná, do Rio Grande do Sul e de Mato Grosso; a conquista de Goiás. Anais do Museu Paulista. tomo I, 1922, p. 419.

${ }^{6}$ Por ter pesquisado sobretudo a história de São Paulo, Taunay foi reconhecido na época e posteriormente como o "historiador de São Paulo". "Até hoje nenhum outro historiador brasileiro merece com mais justiça esta definição em relação a qualquer cidade, estado ou região do país. Desde que cronistas do século XVIII, como frei Gaspar da Madre de Deus e Pedro Taques de Almeida Leme, com seus relatos e genealogias, compuseram a imagem fundadora dos paulistas, a historiografia de São Paulo limitara-se a episódios e a figuras ilustres. Somente com o aparecimento das primeiras obras de Taunay na década de 1910 é que se iniciou o estudo sistemático de diversos temas fundamentais para o conhecimento da história de São Paulo". MESGRAVIS, Laima. Afonso de Escragnolle Taunay, o historiador de São Paulo. In: TAUNAY, Afonso de E. São Paulo nos primeiros anos: ensaio de reconstituição social; São Paulo no século XVI: história da vila piratiningana. São Paulo: Paz e Terra, 2003, p. 3 (As primeiras edições destes livros são, respectivamente, 1920 e 1921). ${ }^{7}$ Antônio Celso Ferreira ressalta que o "historiador típico dos institutos era o homem erudito que transitava, com fluência, por diferentes domínios intelectuais". O modelo idealizado era do "homem público, pesquisador sério, escritor de múltiplas habilidades e, além de tudo, dotado de uma bela oratória. Entre os selecionados das gerações mais novas, Afonso de Taunay parecia reunir todas essas qualidades, daí ter sido tão insistentemente aclamado". FERREIRA, Antônio Celso. A epopeia bandeirante: letrados, instituições, invenção histórica (1870-1940). São Paulo: Unesp, 2002, p. 123. 
Dentre os temas por ele pesquisados não ficou esquecida a História antiga da abadia de São Paulo ${ }^{8}$ em que narrou a concessão de terras para a construção do Mosteiro de São Bento. Em suas palavras: o segundo lugar "mais ilustre da vila, o lugar onde se assentara a taba do velho Tibiriçá, o glorioso índio que realizara a aproximação euro-americana e permitira o surto da civilização no planalto". ${ }^{9}$ Para construir essa imagem gloriosa de Tibiriçá, um dos fundamentos da formação dos paulistas, Taunay ressaltou a relevância emblemática de alguns locais que compuseram o cenário da história da cidade:

Em 1598, erguia o austero frei Mauro Teixeira, monge vicentino, a ermida de Nossa Senhora de Monte Serrat e uma cela contígua, onde deveria passar alguns anos de vida cenobítica. A essa capela concedeu o capitão-mor Jorge Corrêa duas sesmarias. Só em 1600, porém, é que se realizou a fundação regular do Mosteiro, e por frei Mateus da Ascensão, especialmente enviado a São Paulo com outros confrades pelo providencial do Brasil quando da visita do governador geral d. Francisco de Souza.

Passaram-lhe então os oficiais da Câmara uma carta de chãos a 15 de abril 'por lhes constar que se tratava de serviço de Deus e do seu servo bemaventurado são Bento, motivo pelo qual lhes davam e haviam por dados os ditos chãos para convento, mosteiro ou casa do dito santo, isentos de todo tributo e pensão até o fim do mundo'. ${ }^{10}$

A relevância conferida por Taunay para o papel dos beneditinos no Brasil foi narrada na referida obra e destacada por ele em outros textos e também no cotidiano de sua correspondência. A relação pessoal que ele manteve com os beneditinos foi tão importante para sua iniciação historiográfica e formação intelectual que, no ano em que se comemorou o centenário de seu nascimento, em 1976, vários autores se referiram a ele como um trabalhador beneditino ao contarem sua atuação nos empreendimentos educacionais do Mosteiro de São Bento, bem como ao tratarem de sua dedicação aos estudos históricos. O próprio Taunay conferia importância a essa denominação, pois para terminar o prefácio de sua História antiga da abadia de São Paulo afirmou que a nova geração de homens dedicados

\footnotetext{
${ }^{8}$ TAUNAY, Afonso de E. História antiga da abadia de São Paulo (1598-1772). São Paulo: Tipografia Ideal; Heitor L. Canton, 1927.

${ }^{9}$ Ibidem, p. 24.

${ }^{10}$ TAUNAY, Afonso de E. São Paulo nos primeiros anos..., op. cit., p. 69-70.
} 
a continuar a tarefa de d. Miguel Kruse ${ }^{11}$ no Mosteiro de São Bento deveria se inspirar no exemplo daqueles que "impuseram ao vocabulário da intelectualidade de todas as línguas cultas do Universo o substantivo e o adjetivo "beneditino". ${ }^{22}$

Vários artigos destinados a homenagear Afonso de Taunay circularam pela imprensa em 1976, ano em que se comemorou o centenário de nascimento do autor. O jornalista Hélio Damante (1919-2002) publicou no jornal O Estado de S. Paulo de 11 de julho de 1976 uma síntese, bastante elogiosa, da trajetória de Taunay dividida em dois subtítulos: $\mathrm{O}$ humanista e $\mathrm{O}$ historiador. Para introduzir este segundo subtítulo Damante narrou:

Será à sombra do velho Mosteiro de S. Bento - Taunay nasceu, sabe-se hoje, no dia em que morreu o pai dos monges (11 de julho), conforme o novo calendário universal dos santos - que o professor da Politécnica será cada vez menos engenheiro e cada vez mais historiador.

Professor de História Universal no Colégio de S. Bento e depois na Faculdade de Filosofia de S. Bento, a primeira do país, fundada por d. Miguel Kruse, que ao mesmo tempo faria aluir as paredes de taipa do velho mosteiro e erguer o novo, Taunay desenvolve sua verdadeira vocação. $\mathrm{Na}$ opulenta biblioteca dos monges, onde não faltam códices e documentos, identifica São Paulo dos primeiros tempos e descobre os segredos de Amador Bueno. A própria abadia merece-lhe um estudo quase sentimental: História antiga da abadia de São Paulo (1598-1772). ${ }^{13}$

A comemoração mais significativa do centenário de Taunay foi realizada pela Secretaria da Cultura, Ciência e Tecnologia (Departamento de Artes e Ciências Humanas) de São Paulo que propôs o Curso de História Afonso D’ E. Taunay. Esse curso, divulgado amplamente pela imprensa paulista e carioca, foi realizado no Instituto Histórico e Geográfico de São Paulo e contou com nove estudos a respeito da vida e obra do historiador e a publicação destes e de outros

\footnotetext{
${ }^{11}$ Taunay afirmou em 1927 que "desde 1900 há, portanto, quase trinta anos, dia-a-dia, em São Paulo, acompanho a ação beneditina honrado com o apreço constante dos dignos religiosos e a amizade quase trintenária de seu prelado, o sr. d. Miguel Kruse. Decano do corpo docente do seu ginásio, fundado em 1903, pude de perto, quase na intimidade, verificar o intenso amor com que os beneditinos de $\mathrm{S}$. Paulo têm, ao mesmo tempo, servido a causa da Igreja e da pátria brasileira". In: TAUNAY, Afonso de E. História antiga da abadia de São Paulo..., op. cit., p. IX.

${ }^{12}$ TAUNAY, Afonso de E. História antiga da abadia de São Paulo..., op. cit., p. X.

${ }^{13}$ DAMANTE, Hélio. No centenário de Afonso de Taunay. Jornal O Estado de S. Paulo, 11 de julho de 1976. Arquivo dos Acadêmicos da Academia Brasileira de Letras, Arquivo Afonso de Taunay - Série 3 - Hemeroteca.
} 
quatro trabalhos em um número especial da Revista do Arquivo Municipal. ${ }^{14}$ Dentre os estudos, foi reservado um espaço para o tema Afonso de Taunay e o Mosteiro de São Bento. ${ }^{15}$ Assim, em diversos textos e por toda obra de Taunay, a importância da presença beneditina em sua trajetória se fez presente.

A presença beneditina marcou a visão católica/providencialista que em diversos momentos mostra-se perceptível na escrita da história de Taunay. A providência divina foi utilizada como explicação de alguns acontecimentos pesquisados por ele e encontra-se espalhada por sua obra. Anos antes de falecer, em 1953, na introdução de Relatos monçoeiros, ao tratar da importância do rio Tietê para a "construção territorial do imenso Brasil ocidental", Taunay fez uso do providencialismo para destacar as dificuldades enfrentadas pelos bandeirantes e, como consequência, ressaltar a resistência destes:

Inçado de dificuldades, entrecortado pelas barreiras das itaipavas e dos saltos, como que a providência propositalmente lhe tornara áspero e penoso o vencimento do dilatado curso para manter exercitadas as qualidades de resistência e a capacidade de sofrimento dos seus navegadores rudes. ${ }^{16}$

A formação católica de Taunay foi reforçada pelo contato cotidiano com os beneditinos desde 1897 quando foi hóspede por três anos do Mosteiro de São Bento do Rio de Janeiro enquanto cursava a Escola Politécnica. Taunay descreveu esse contato como algo que marcou definitivamente sua vida:

Jamais poderei esquecer a formidável impressão que me causou penetrar pela primeira vez no grandioso claustro de cantaria do Mosteiro fluminense, o cemitério monástico onde sobre as lousas se inscrevem os milésimos de três séculos. Foi como que uma impressão de deslumbramento, a meus olhos de adolescente, esta visão tão impressionadora quanto majestosa, da continuidade poderosa daquela obra beneditina quase cinco vezes mais velha do que aquilo que ali eu tinha presente. Nunca vi se me apresentar

\footnotetext{
${ }^{14}$ REVISTA do Arquivo Municipal de São Paulo, ano 40, no 189, jan./jun. 1977. Encontra-se, dentre os textos publicados, “Taunay e a história do Brasil” de José Honório Rodrigues, p. 83-100.

${ }^{15}$ REVISTA do Arquivo Municipal de São Paulo, op. cit., p. 63-72.

${ }^{16}$ TAUNAY, Afonso de E. Relatos monçoeiros. Belo Horizonte: Ed. Itatiaia; São Paulo: Ed. da Universidade de São Paulo, 1981, p. 11. (Primeira edição: São Paulo: Martins, 1953)
} 
com tamanho vigor outra imagem concreta da promessa de N. S. Jesus Cristo ao Príncipe de seus Apóstolos, sobre a eternidade de sua Igreja. ${ }^{17}$

Em 1899, faltando um ano para concluir o curso de engenharia no Rio de Janeiro, Taunay foi para São Paulo trabalhar na Escola Politécnica e relatou, em texto escrito em 1927, que a partir desse momento passou a acompanhar dia-adia "a ação beneditina honrado com o apreço constante dos dignos religiosos e a amizade quase trintenária de seu prelado, o sr. d. Miguel Kruse". ${ }^{18}$

Essa convivência entre Taunay e os beneditinos foi intensificada com a criação do Ginásio de São Bento em 1903 e com a fundação, em 1908, por dom Miguel Kruse, abade do Mosteiro de São Bento, da Faculdade Livre de Filosofia e Letras de São Bento. Com os cursos de filosofia e letras instalados, essa instituição, primeira faculdade livre de filosofia do Brasil, ${ }^{19}$ inaugurou o curso de História Universal em 1911, pioneira tentativa de ascensão dos estudos históricos ao nível universitário, ${ }^{20}$ tendo como professor o jovem engenheiro, formado pela Escola Politécnica do Rio de Janeiro, Afonso de Taunay.

No Mosteiro de São Bento, Taunay apresentou como conferência de abertura do curso de História Universal alguns princípios que fundamentaram tanto a sua narrativa da fundação de São Paulo quanto a escrita das outras obras que produziu nas quatro décadas posteriores àquela noite de 3 de maio de 1911 . Taunay objetivava expor nessa conferência a maneira pela qual todos os autores deveriam escrever a história do Brasil.

A historiografia brasileira já conhecia esta tentativa de definir algumas diretrizes para a escrita da história, pois contava, dentre outros textos, com a dissertação de Carl Friedrich Phillip Von Martius intitulada: Como se deve escrever a história do Brasil e com os estudos de Capistrano de Abreu, especialmente

\footnotetext{
${ }^{17}$ TAUNAY, Afonso de E. História antiga da abadia de São Paulo..., op. cit, p. VIII.

${ }^{18}$ Ibidem, p. IX.

${ }^{19}$ A Reforma Educacional Leôncio de Carvalho de 1879 havia instituído os chamados "cursos livres" e previsto as "faculdades livres". Em 1891, na Reforma Benjamin Constant, reaparece esta solução para os cursos de ensino superior no país. Essa reforma permitia "a qualquer indivíduo ou associação particular fundar cursos ou estabelecimentos de ensino superior, e uma vez que o funcionamento destes fosse considerado regular e fosse adotado o programa de curso ou faculdade federal, aqueles cursos e estabelecimentos gozariam dos privilégios destes". NAGLE, Jorge. Educação e sociedade na Primeira República. 2a ed. Rio de Janeiro: DP\&A, 2001, p. 205.

${ }^{20}$ MATOS, Odilon Nogueira. Afonso de Taunay historiador de São Paulo e do Brasil: perfil biográfico e ensaio bibliográfico. São Paulo: Museu Paulista, 1977, p. 27.
} 
os artigos a respeito da obra de Francisco Adolfo de Varnhagen. ${ }^{21}$ No entanto, a iniciativa de Afonso de Taunay diferenciou-se das anteriores porque incorporava um elemento novo. Essa conferência, pronunciada por ele em 1911, foi emblemática porque compôs a primeira tentativa de institucionalização do estudo da história no Brasil em um curso de nível superior. No Brasil, a pesquisa histórica realizava-se desde o século XIX, preponderantemente nos institutos históricos, e era desenvolvida por homens de letras formados nas mais diversas áreas. ${ }^{22}$

A conferência ${ }^{23}$ a respeito dos "princípios gerais da moderna crítica histórica" teve início com a narrativa — bastante adequada ao se considerar o público que ouvia Taunay no Mosteiro de São Bento — de um episódio decorrente da abertura dos arquivos do Vaticano em 1881 pelo então papa Leão XIII que decidiu franqueá-los a estudiosos dotados de credenciais. Conta Taunay que alguém interpelou o papa afirmando que aquela atitude seria imprudente porque traria à luz documentos confidenciais que poderiam causar surpresas desagradáveis e, sobretudo, possibilitariam aos inimigos da Igreja Católica forjar armas contra a Santa Sé a partir de elementos fornecidos por esses materiais colocados à disposição.

Diante de tal preocupação o papa teria respondido:

em hipótese alguma devemos temer a verdade. [...] O primeiro dos princípios da História é não ousar mentir, de leve que seja, o segundo não recear dizer a verdade, em hipótese alguma, lembrando-se de que acima de tudo é preciso que não dê ensejo a que pareça inspirada pela lisonja e pela animosidade. ${ }^{24}$

Taunay afirmou que nas palavras do sumo pontífice encontrava-se "a síntese dos sentimentos que devem inspirar o historiador" e, com esse direcionamento,

\footnotetext{
${ }^{21}$ ABREU, Capistrano de. Necrológio de Francisco Adolfo de Varnhagen, visconde de Porto Seguro; Idem, Sobre o visconde de Porto Seguro Ensaios e Estudos (Crítica e História). 1ª série, $2^{a}$ ed. Rio de Janeiro: Civilização Brasileira; Brasília, INL, 1975.

${ }^{22}$ Os estudos históricos haviam passado pela profissionalização universitária na Alemanha, após 1848, na maior parte dos países europeus e Japão, depois de 1870, e na Grã-Bretanha e nos Países Baixos, pouco tempo depois. IGGERS, Georg G. Historiografy in the twentieth century: from scientific objectivity to the postmodern challenge. Edition including a new epilogue by the author. Middletown, Connecticut: Wesleyan University Press, 2005.

${ }^{23}$ Esta conferência também foi analisada por Ana Cláudia Brefe que concluiu: "Defensor inveterado dos documentos e da submissão do historiador aos seus imperativos, a prática historiográfica de Taunay, e sobretudo seu trabalho realizado na composição da Seção de História do Museu Paulista, mostram que há uma distância, às vezes significativa, entre aquilo que ele teorizou e o que de fato realizou". BREFE, op. cit., p. 76-77.

${ }^{24}$ TAUNAY, Afonso de E. Os princípios gerais da moderna crítica histórica..., op. cit., p. 325.
} 
lançou mão de uma imagem forte e importante para a História que acreditava ser adequada para o período: "Precisa o historiador de hoje iluminar os assuntos com os mais possantes focos de que lhe seja possível munir-se, no arsenal das ciências auxiliares da História; não arriscar um passo sem que se sinta apoiado por incompressível terreno". ${ }^{25}$ Ao fazer referência às ciências auxiliares, Taunay não se remetia à abertura de diálogo com as ciências sociais proposta por diversas tendências historiográficas desde o início do século $\mathrm{XX},{ }^{26}$ mas sim ao apoio das seguintes ciências auxiliares: "a filologia, a epigrafia, a paleografia, a diplomática, sem falar nos conhecimentos de linguística correspondentes a certas regiões e o estudo da interpretação das inscrições em casos especiais". ${ }^{27}$

Com esses "possantes focos", inspirados pela busca da verdade e amparados pelas ciências auxiliares, o historiador deveria se dirigir às fontes existentes disposto a fechar os ouvidos a tudo que não ditasse a verdade, evitando assim, assemelhar-se àqueles a quem a "história assusta". ${ }^{28}$ Assim, Taunay apresentou o princípio da "verdade ditada pelo documento", referência que expõe o cerne desse empreendimento de escrita da história.

Na sequência do texto, Taunay expôs a primeira justificativa para a aceitação desse princípio da verdade remetendo-se às imposições do meio, ou seja, à crítica. Com o surgimento de novos estudos e com a facilidade de acesso a documentos antes restritos ou desconhecidos, esconder a verdade passou a significar o maior perigo para o historiador, pois se os amigos se calarem ou encobrirem suas parcialidades, os adversários estarão atentos e prontos a "pro-

\footnotetext{
${ }^{25}$ Ibidem, p. 325-326.

26 “A necessidade da relação entre a história e as demais ciências sociais tornou-se uma tautologia, reconhecida pelos especialistas nas diversas historiografias nacionais, embora se discuta o grau destas aproximações, que vão desde contatos esporádicos e empréstimos metodológicos discretos até o trabalho interdisciplinar dos area studies, desenvolvido nos EUA dos anos 1950, ou a interpenetração da pesquisa antropológica e histórica no México atual. Na França, com as duas primeiras gerações dos Annales deu-se efetiva abertura para a psicologia, a geografia, a estatística, a sociologia e a economia, à medida que se foi afirmando o alargamento temático dos estudos históricos". WEHLING, Arno. Fundamentos e virtualidades da epistemologia da história: algumas questões. Estudos Históricos, Rio de Janeiro, vol. 5, nº 10, 1992, p. 9.

${ }^{27}$ TAUNAY, Afonso de E. Os princípios gerais da moderna crítica histórica..., op. cit., p. 328.

${ }^{28}$ A expressão citada por Taunay pertence, segundo ele, a John Henry Newman (1801-1890), o fundador da Universidade de Dublin. A universidade concebida por Newman era uma instituição que privilegiava a cultura geral literária e humanística, aos moldes das Universidades de Oxford e Cambridge, portanto dedicava-se ao ensino do saber universal e defendia a busca da verdade. Cf. TEIXEIRA. Anísio. A universidade de ontem e de hoje. Revista Brasileira de Estudos Pedagógicos. Rio de Janeiro, v. 42, n. 95, jul./set. 1964. p. 27-47; Idem, Uma perspectiva da educação superior no Brasil. Revista Brasileira de Estudos Pedagógicos. Brasília, v. 50, n 111, jul./set. 1968, p. 21-82.
} 
clamar retumbantemente, com tamanho estridor que se farão ouvidos em todos os recintos, os mais violentos dos baldões atingirá em cheio o historiador: o de narrador parcial e desleal". ${ }^{29}$ Portanto, afirma Taunay, para que essa acusação não seja feita, o historiador deve "dizer a verdade, toda a verdade, nada mais do que a verdade". 30

Entretanto, como é possível ao historiador alcançar essa verdade? Taunay tentou responder a essa pergunta no decorrer da conferência a partir da citação de diversos autores. No entanto, ao fazer uso de trechos de obras ele não mencionou a autoria das afirmações. Nenhuma obra foi apresentada por Taunay como um modelo. Contudo, chama a atenção em seu texto a seguinte frase citada na segunda página: "a história se faz com os documentos". ${ }^{31}$ Não seria mera coincidência ser esta a primeira frase do capítulo 1 intitulado "A busca dos documentos" do livro Introdução aos estudos históricos de Charles-Victor Langlois (1863-1929) e Charles Seignobos (1854-1942). ${ }^{32}$

Redigido entre 1896 e 1897 "com o escopo de informar os novos alunos da Sorbonne do que são e do que devem ser os estudos históricos", ${ }^{33}$ o livro Introdução aos estudos históricos foi utilizado por Taunay para o mesmo fim pedagógico, ou seja, como um manual de procedimentos que deveria instruir os

\footnotetext{
${ }^{29}$ TAUNAY, Afonso de E. Os princípios gerais da moderna crítica histórica..., op. cit., p. 326.

${ }^{30}$ Ibidem, p. 326.

31 “'O respeito pelo documento histórico e o controle da subjetividade são as regras de ouro daquilo que vai passar a chamar-se escola metódica. Mais tarde, ela será de algum modo vituperada e caricaturizada pela escola dos Annales, com a denominação de história historicizante". Cf. DOSSE, François. Ahistória à prova do tempo: da história em migalhas ao resgate do sentido. São Paulo: Editora Unesp, 2001, p. 17. 32 “A história científica alemã conta, na França, com dois "tradutores” principais: a Revue Historique e os manuais de metodologia da história, dos quais o mais reconhecido e difundido foi o de Ch. Langlois e Ch. Seignobos, Introduction aux études historiques, de 1898. Além desses “tradutores" havia também as universidades e outras instituições de pesquisa, catalogação e edição de documentos. [...] Esse manual definirá o espírito que anima a pesquisa histórica de então: o "espírito positivo", antimetafísico. [...] O desejo de constituir a história sob bases científicas, positivas, expressa-se, portanto, na ênfase ao dado, ao evento, no cultivo à dúvida, à observação, à erudição e na recusa dos modelos literários e metafísicos. Esse manual, que formará gerações de historiadores, exprime com exatidão o ponto de vista da "história metódica" que dominou a produção histórica francesa de 1880 a 1945". REIS, José Carlos. A escola metódica, dita "positivista”. In: A História entre a Filosofia e a Ciência. $3^{\text {a }}$ ed. Belo Horizonte: Autêntica, 2004, p. 21-24. A Revue Historique lançada por Gabriel Monod em 1876 vinculava-se à tradição humanista renascentista e à erudição dos beneditinos de Saint-Maur, no entanto, não deixava de reconhecer a influência de historiadores alemães, tais como: Boeck, Niebuhr, Mommsen, Savigny, Ranke, Waitz e Gervinus. BOURDÉ, Guy; MARTIN, Hervé. A escola metódica. In: As escolas históricas. Portugal: Publicações Europa-América, 1983. ${ }^{33}$ LANGLOIS, Ch. V.; SEIGNOBOS, Ch. Introdução aos estudos históricos. Tradução de Laerte de Almeida Morais. São Paulo: Renascença, 1946, p. 12.
} 
alunos quanto às leituras que fariam naquele curso em São Paulo e no possível ofício futuro deles como historiadores. Portanto, ao resumir partes importantes dessa obra, Taunay antecipou a tradução do livro de Langlois e Seignobos para o português no Brasil que somente aconteceu em 1944. Dessa forma, o autor forneceu aos estudantes em 1911 e aos leitores da Revista do Instituto Histórico e Geográfico de São Paulo em 1914, ano em que a conferência foi publicada, ${ }^{34}$ um resumo dos princípios que fundamentavam os estudos históricos na França em fins do século XIX e, ainda, naquelas primeiras décadas do século XX. ${ }^{35}$

A conferência proferida por Taunay apresenta-se, portanto, como um resumo do livro de Langlois e Seignobos entremeado com citações de outros autores e exemplos que, ora compõem esse livro, ora resultam de outras leituras realizadas por Taunay. Assim, a partir da identificação da fonte não citada, mas utilizada pelo autor, foi possível cotejar a conferência e o livro Introdução aos estudos históricos na tentativa de identificar os elementos destacados por Taunay dentre aqueles tratados pelos autores franceses.

Após a apresentação da verdade como fundamento principal do ofício do historiador, Taunay passou a dissertar a respeito dos procedimentos adequados para o trabalho com os documentos:

A história se faz com os documentos, os atos cujos vestígios materiais desapareceram estão para ela perdidos e quando muito podem concentrarse no domínio das reminiscências coletivas. Onde desapareceram os documentos, chegam os extremados a avançar, cessa a história. Deve o historiador moderno começar por investigar e recolher documentos, cultivar intensamente essa ciência a que os alemães batizaram Heurística. Ninguém pode hoje descrever uma época fazendo trabalho original sem

\footnotetext{
${ }^{34}$ Antônio Celso Ferreira, ao analisar as publicações da Revista do IHGSP, afirma que "quase nada se fala dos historiadores metódicos". Este texto de Taunay publicado nesta Revista comprova a evidência assinalada pelo autor, pois na conferência não há citações dos autores metódicos. No entanto, os procedimentos expostos por Taunay mostram a referência direta ao livro Introdução aos estudos históricos de Langlois e Seignobos. O autor destaca ainda que os autores nacionais, tais como Capistrano e Varnhagen, apareciam mais nas citações. Esta característica também é válida para a produção de Taunay, pois em sua obra o diálogo com a historiografia nacional é constante, como veremos adiante. FERREIRA, op. cit., p.124-125.

${ }^{35}$ Le Goff, ao discutir as implicações da História entendida como ciência, reconhece a importância da afirmação de Langlois e Seignobos, "sem documentos não há História”, como uma "fórmula notável, que constitui profissão de fé fundamental do historiador”, pois mesmo após a ampliação da noção de documento e a problematização quanto aos seus usos e significados, o historiador não abandonou o trabalho com as fontes. LE GOFF, Jacques. História e memória. $5^{\mathrm{a}}$ ed. Campinas, São Paulo: Unicamp, 2003, p. 105.
} 
se dar a um trabalho imenso de pesquisa e de cotejo. É na obediência dessa ordem de ideias que reside a força, a superioridade e a convicção dos historiadores e eruditos hodiernos. ${ }^{36}$

Apesar de ter considerado extremada a conclusão de que onde não há documentos cessa a história, Taunay continuou seu texto em companhia de Langlois, autor do primeiro capítulo da Introdução, ressaltando a importância da busca dos documentos e acrescentando um exemplo que, segundo ele, demonstrava o quanto a descoberta de novas fontes poderia mudar a história e, até mesmo, "inutilizar" obras reconhecidas.

Taunay ressaltou a importância da obra de Ludwig Von Pastor (1854-1928), o historiador alemão que a partir do acesso irrestrito aos arquivos do Vaticano escreveu em dezesseis volumes uma História dos papas (publicada entre 1886 e 1933). Taunay, que utilizou essa obra anos mais tarde para traçar a história dos beneditinos na América e no Brasil, ${ }^{37}$ teve acesso a ela na biblioteca do Mosteiro de São Bento de São Paulo e, mais uma vez, na conferência imprimiu a sua marca remetendo-se ao assunto tratado no início da apresentação, ou seja, a abertura dos arquivos do Vaticano, e acrescentando outras leituras além do livro Introdução que estava resumindo.

Bastante impressionado com a obra de Ludwig Von Pastor, Taunay afirmou que, apesar de no prefácio o autor ter ponderado "modestamente" que apenas lhe assistia "a convicção de haver encetado útil empresa não porque tinha a capacidade de traçar a síntese dos trabalhos profundos dos que estudaram a vida da Santa Sé, mas só porque lhe foi dado a devassar os arquivos vaticanos", ${ }^{38}$ a obra quase anulava as precedentes escritas por autores como Leopold Von Ranke e Jacob Burckhardt que não tiveram acesso às fontes trabalhadas por Pastor.

Os esforços extraordinários desses historiadores para tirar premissas e conclusões da deficiência das fontes compulsadas, mal grado toda a ener-

\footnotetext{
${ }^{36}$ TAUNAY, Afonso de E. Os princípios gerais da moderna crítica histórica..., op. cit., p. 326-327 (grifo nosso).

${ }^{37}$ Cf. especialmente o capítulo 2 da obra: TAUNAY, Afonso de E. História antiga da abadia de São Paulo..., op. cit.

${ }^{38}$ TAUNAY, Afonso de E. Os princípios gerais da moderna crítica histórica..., op. cit., p. 327.
} 
gia de sua pujança mental, foram totalmente inutilizados pela aparição de uma série de documentos inatacáveis, trazidos à luz por Pastor. ${ }^{39}$

Essa conclusão de Taunay, em relação ao estudo de Ludwig Von Pastor, é muito importante para a compreensão de sua própria obra, pois a publicação de uma série de documentos inéditos foi apontada por Taunay como decisiva para a escrita de sua história de São Paulo. A partir da publicação em 1914 das Atas e do Registro geral da Câmara de São Paulo ${ }^{40}$ Taunay pôde explorar "o mais pitoresco terreno ainda absolutamente virgem"41 como ele afirmou no prefácio, assinado em julho de 1919, de São Paulo nos primeiros anos. Desde 1917, Taunay apresentava nas colunas do jornal Correio Paulistano os resultados preliminares de seu trabalho com a documentação e, em 1920, publicou a pesquisa em livro com a ampliação e revisão dos temas. Esse foi um elemento constante na produção de Taunay e pode-se dizer que na escrita de um amplo rol de autores que produziram nas primeiras décadas do século XX, ou seja, a descoberta de novos documentos, muitas vezes, guiou a escrita dessa história.

No entanto, além da descoberta do documento, facilitada pelo crescimento de inventários críticos, transcrições e publicações, cabia ao historiador a crítica dos documentos que somente poderia ser realizada com a ajuda das ciências auxiliares. Na conferência, antes de tratar de cada passo a ser seguido para a realização da crítica interna e externa do documento, Taunay introduziu uma afirmação gerada pela complexidade dos procedimentos que ele ainda apresentaria:

Estas imposições do critério moderno provocaram no campo da história, como já o haviam feito no de todas as ciências, o aparecimento das especializações, a restrição e a particularização dos assuntos. As grandes obras de história universal ou de história nacional que outrora bastaram para o esforço de um homem, só vêm a ser substituídas pelas monografias, cada vez mais numerosas e pormenorizadas e pelos escorços biográficos. A

\footnotetext{
${ }^{39}$ Ibidem, p. 327.

${ }^{40}$ A publicação das Atas e do Registro geral da Câmara de São Paulo foi financiada pelo governo municipal e, mais especificamente, deveu-se ao empenho de Washington Luís. Ele foi deputado estadual entre 1904 e 1906, secretário estadual de Justiça entre 1906 e 1912 e prefeito da cidade de São Paulo entre 1914 e 1919, período em que foram publicados estes documentos utilizados por Taunay. ${ }^{41}$ TAUNAY, Afonso de E. São Paulo nos primeiros anos..., op. cit., p. 15.
} 
caçada ao documento torna-se cada dia mais áspera; muito já foi colhido, mas imenso há ainda que respigar. ${ }^{42}$

Neste trecho o autor retomou, de certa maneira, a conclusão apresentada a respeito da obra de Ludwig Von Pastor, pois afirmou que não era mais tempo de histórias nacionais porque a disciplina exigia tamanho rigor metodológico que era impossível a um homem dar conta de pesquisar todos os temas de um período em suas generalidades. Nesse sentido, considerou que aquele era o tempo das monografias. Momento adequado para a realização de estudos localizados que, a partir de documentos inéditos, pudessem explicar o recorte estabelecido dentro das possibilidades temáticas da história nacional. Era uma história que por "recortar seus objetos, localizando-os em momentos precisos" 43 lidava com a temporalidade curta. No caso da obra de Taunay, essa característica se torna evidente, pois, no intuito de tratar de temas que perpassavam os séculos, ele elaborou estudos pormenorizados a respeito de recortes temporais precisos que, quando reunidos, deram origem às suas histórias gerais das Bandeiras e do café. É importante ressaltar esse elemento porque quando se analisa o conjunto da obra de Taunay pode-se ter a impressão de que ele estudou longos períodos, mas na verdade, ele empreendeu recortes temporais e temáticos precisos dentro das possibilidades da história do Brasil e apontou o método como justificativa aos seus críticos que, ansiosos por sínteses, se impacientaram após a publicação do segundo tomo da História geral das Bandeiras paulistas e lhe solicitaram uma síntese a respeito do bandeirismo. Os críticos mal podiam prever que aquele era o segundo volume de uma obra composta por onze tomos.

Aos dois volumes da História geral das Bandeiras paulistas que a este antecedem, encetamos a chamar a atenção dos leitores para o fato de que

\footnotetext{
${ }^{42}$ TAUNAY, Afonso de E. Os princípios gerais da moderna crítica histórica..., op. cit., p. 328 (grifo nosso).

43 “A ênfase na empiria, dada pelas fontes, traz o conhecimento histórico para o tempo dos humanos, mostrando, ainda que involuntariamente, que a abstração metafísica é a responsável por um olhar que dilui os homens nas esferas do universal”. D`ALESSIO, Márcia Mansor. Práticas historiográficas: um estudo. In: MALATIAN, Teresa; LEME, Marisa Saenz; MANOEL, Ivan Aparecido (orgs.). As múltiplas dimensões da política e da narrativa. Franca, São Paulo: Unesp, 2003, p. 189-190.
} 
se lhes oferecia uma obra de análise de documentos muito numerosos, jamais coordenados, e, em sua grande maioria, inéditos.

Não nos era, portanto, absolutamente possível cogitar ou retraçar sínteses daquilo que ainda não fora exposto e ainda menos analisado.

Mereceram estes dois tomos apreciações numerosas e sobretudo as críticas muito numerosas assinadas por alguns dos mais prestigiosos nomes das letras brasileiras. [...] Houve também quem, sofregamente, já quisesse, nestes volumes, encontrar apreciações do conjunto dos fatos do bandeirantismo - quando eles mal historiam a fase inicial do movimento antitordesilhano - e ao autor o arguisse.

Seja nos permitido contestar esta impaciência lembrando aos reparadores quanto ao estado atual dos estudos sobre o bandeirismo é ainda o da fase da descoberta dos documentos, o da interpretação dos elementos esparsos e de reunião por vezes difícil, exigindo indispensável concatenação como a que intentamos realizar.

Vencidos estes óbices, compendiados os ensinamentos das fontes, postos os valores em relevo caberá aí - agora a tempo e a hora - o enunciado das sínteses. ${ }^{44}$

Para "compendiar os ensinamentos das fontes" muitos esforços precisavam se realizar. O trabalho de descobrir o documento, muitas vezes solicitar a cópia, "interpretar os elementos esparsos" com o auxílio das ciências auxiliares e dos estudos existentes a respeito do tema e apresentar a "reunião concatenada" desses elementos significava a realização de "monografias pormenorizadas" que somente chegariam à síntese após um número extenso de pesquisas. Nesse sentido, esse não era o momento de fazer a síntese ${ }^{45}$ era sim a hora de aplicar os procedimentos e produzir monografias para o adequado estudo dos temas.

O que se definia como a forma adequada de se escrever a história, portanto, era a composição de monografias exaustivas a respeito de um tema. Foi isto que Taunay objetivou fazer nos onze volumes da História geral das Bandeiras paulistas diferenciando-se da História geral do Brasil de Francisco Adolfo de

\footnotetext{
${ }^{44}$ TAUNAY, Afonso de E. História geral das Bandeiras paulistas: escrita à vista de avultada documentação inédita dos arquivos brasileiros, espanhóis e portugueses. Tomo terceiro (1641-1651). São Paulo: Tipografia Ideal; H. L. Canton, 1927, p. VII. (grifo nosso)

${ }^{45}$ É importante destacar que Taunay se mantinha alheio às críticas já formuladas na França a essa ideia de uma História pormenorizada. Vale lembrar que, em 1900, Henry Berr, filósofo e historiador francês, fundou a Revue de Synthèse Historique.
} 
Varnhagen. No cenário nacional outro autor havia chegado a essa conclusão muitos anos antes: "Agora o que se precisa é de monografias conscienciosas", 46 afirmou Capistrano de Abreu em 1882 no texto em que avaliou a obra de Varnhagen, o que, como será tratado adiante, assumiu grande relevância em relação às posições assumidas por Taunay.

Na segunda parte da conferência, Afonso de Taunay detalhou a "série de operações das mais trabalhosas" ${ }^{\text {"47 }}$ que apresentou no trecho citado acima como justificativa aos críticos do trabalho realizado por ele até 1927 . Assim, o autor iniciou o resumo do Livro II da Introdução. ${ }^{48}$ No primeiro capítulo desse segundo livro intitulado "Condições gerais do conhecimento histórico", Langlois e Seignobos problematizaram a afirmação de que a "história se faz com documentos" e é importante retomar aqui os argumentos apresentados pelos autores para a compreensão das afirmações feitas por Taunay na conferência.

Os fatos não podem ser empiricamente conhecidos senão de dois modos: ou diretamente, quando observados no momento em que se produzem, ou indiretamente, quando estudados nos traços que deixaram. [...] Ora, a característica dos "fatos históricos" é só serem conhecidos indiretamente, através dos traços. O conhecimento histórico é, por essência, um conhecimento indireto. [...] Só pelos traços que deixaram podem os fatos passados ser por nós conhecidos. Estes traços denominados “documentos" são observados diretamente pelo historiador, é verdade; mas depois de os examinar, nada mais há a observar; a partir daí o historiador procede por via de raciocínio, para tentar extrair dos traços, até onde isso for possível, a verdade dos fatos. O documento é o ponto de partida; o fato o ponto de chegada. ${ }^{49}$

Fundamentado nestes argumentos, Taunay apresentou os principais aspectos, segundo sua concepção, da crítica externa começando por aquilo que traduziu como crítica de inspeção e que pode ser entendida como a crítica de restauração. Esta crítica se referia à comparação, quando possível, da cópia do documento com o original conferindo à cópia a autenticidade ou o confronto entre as edições

\footnotetext{
${ }^{46}$ ABREU, Capistrano de. Sobre o visconde de Porto Seguro. Ensaios e Estudos (Crítica e História). $1^{\mathrm{a}}$ série, $2^{\mathrm{a}}$ ed. Rio de Janeiro: Civilização Brasileira; Brasília, INL, 1975, p. 139.

${ }^{47}$ TAUNAY, Afonso de E. Os princípios gerais da moderna crítica histórica..., op. cit., p. 329.

${ }^{48}$ A obra Introdução aos estudos históricos é dividida em Livro I com dois capítulos, Livro II subdividido em capítulo 1, Seção I (Crítica externa) com quatro capítulos, Seção II (Crítica interna) com três capítulos, Livro III com cinco capítulos, Conclusão e dois apêndices.

${ }^{49}$ LANGLOIS, Ch. V.; SEIGNOBOS, Ch., op. cit., p. 44-45.
} 
de um livro. Vencido esse primeiro obstáculo, para a observação do documento caberia ainda, de início, proceder à crítica de origem ou de procedência, pois é "espontânea no espírito humano a tendência em aceitar como autênticas as indicações de proveniência". ${ }^{50}$

A crítica de procedência assumiu grande importância para a história do Brasil escrita nas primeiras décadas do século XX devido aos esforços empreendidos para fixar a autoria de textos encontrados ou de textos conhecidos, mas anônimos ou assinados com pseudônimos. Exemplo significativo tanto pela relevância assumida pelo decifrar da autoria da obra quanto pela influência desempenhada pelo autor que a decifrou foi a "descoberta da criptonímia de Antonil por J. Capistrano de Abreu". Publicada em 1711, Cultura e opulência do Brasil teve sua autoria reputada a André João Antonil, nome que dissimulava a autoria, até 1886 quando Capistrano de Abreu, no prólogo de Informações e fragmentos históricos do padre José de Anchieta, escreveu que para o entendimento do período das minas não mais se precisava ler Rocha Pita, podia-se consultar “André João Antonil, ou, para dizer o verdadeiro nome, João Antônio Andreoni, porque Antonil era o pseudônimo - para ver o entusiasmo que a terra despertara" ${ }^{51}$ Animado por essa descoberta, Afonso de Taunay, quando convidado pela Companhia Melhoramentos para presidir uma série de reimpressões de livros raros brasileiros, coordenou, em 1923, a reimpressão de Cultura e opulência do Brasil a partir do confronto com a primeira edição e compôs um estudo biobibliográfico em que apresentou os temas abordados no livro, aspectos da biografia do autor e a descoberta de Capistrano.

Portanto, os procedimentos destacados por Taunay na conferência de 1911 podem ser encontrados em diversas obras suas, principalmente em muitas passagens em que afirmou a dificuldade de se escrever a história. Voltando à conferência, disse Taunay:

Pensam os profanos que tudo se acha pronto para o historiador quando conseguiu colecionar os textos relativos aos acontecimentos de que é relator. Basta-lhe agora reuni-los por meio de algumas frases de transi-

\footnotetext{
${ }^{50}$ TAUNAY, Afonso de E. Os princípios gerais da moderna crítica histórica..., op. cit., p. 329.

${ }^{51}$ TAUNAY, Afonso de E. Antonil e sua obra. Estudo biobibliográfico. In: ANTONIL, André João. Cultura e opulência no Brasil. 2a ed. São Paulo: Melhoramentos; Brasília, INL, 1976, p. 46.
} 
ção. Isto era bom para os velhos cronistas; exigem os tempos modernos ${ }^{52}$ outra hermenêutica.

Cada fato histórico a esclarecer é uma questão a julgar em que, como em todos os processos, se começa pela audição das testemunhas. ${ }^{53}$

A partir desse trecho, Afonso de Taunay introduziu os aspectos da crítica interna do documento, chamada por Seignobos de crítica de interpretação (hermenêutica). Portanto, à crítica externa Taunay dedicou pouco mais de meia página de seu texto e no restante da conferência, em torno de quinze páginas, voltou-se para as questões que envolvem aquilo que essa concepção da História entendia por interpretação. Acredito que esse seja um ponto fundamental para a compreensão de como se escreveu a história no Brasil, pois contribui para o entendimento das especificidades de significado que esse conceito assumiu para parte significativa dos autores das primeiras décadas do século XX.

Se para essa concepção da História o conhecimento histórico era indireto e somente tornava-se possível por meio do documento, uma vez estabelecido qual o documento seria analisado com o emprego dos procedimentos da crítica externa, caberia ao historiador "analisar" os temas tratados pelos documentos "avaliando e ouvindo quem os produziu". Analisar um documento era "discernir e isolar todas as ideias expressas pelo autor. [...] A interpretação passa por dois graus: o sentido literal e o sentido real". ${ }^{54}$

Para avaliar o sentido literal de um texto, Taunay argumentou, seguindo Seignobos, que era preciso constatar a identidade das testemunhas e ouvilas. Para essa audição das testemunhas entravam em cena os procedimentos linguísticos, pois cada época possui o seu próprio meio de se expressar e os anacronismos saltam diante dos olhos dos eruditos que têm "descoberto tanta

\footnotetext{
${ }^{52}$ Essa referência aos tempos modernos aparece em várias partes desse texto e também em outros livros e na correspondência de Afonso de Taunay. Nicolau Sevcenko, ao estudar a sociedade paulista dos anos 20, destaca a inserção do vocábulo "moderno" no cotidiano daquela cidade, quer seja nos anúncios publicitários de novas tecnologias ou do automobilismo, quer seja nos avanços da medicina, ou das novidades das profissões. Para o autor, “moderno' se torna a palavra-origem, o novo absoluto, a palavra-futuro, a palavra-ação, a palavra-potência, a palavra-libertação, a palavra-alumbramento, a palavra-reencantamento, a palavra-epifania”. SEVCENKO, Nicolau. Orfeu extático na metrópole: São Paulo, sociedade e cultura nos frementes anos 20. São Paulo: Companhia das Letras, 1992, p. 228.

${ }^{53}$ TAUNAY, Afonso de E. Os princípios gerais da moderna crítica histórica..., op. cit., p. 329-330.

${ }^{54}$ LANGLOIS, Ch. V.; SEIGNOBOS, Ch., op. cit., p. 103.
} 
impostura". ${ }^{55}$ Segundo Taunay, o historiador deveria se pautar pelo conhecimento do estilo das épocas, ou seja, a forma empregada por cada período para expressar os acontecimentos, pois esta não se pode burlar.

Na sequência da conferência, Taunay imprimiu novamente o tom de dificuldade do trabalho do historiador reafirmando que os apressados poderiam pensar que todos esses passos bastariam para tratar do tema proposto. Ele explicou que isso várias vezes ocorre porque há uma tendência geral em se "aceitar como verdadeiras as afirmações do documento". No entanto, "contra esta credulidade espontânea, os progressos da atualidade introduziram o que se chamou de a dúvida metódica". ${ }^{56}$ Assim, Taunay enfatizou a concepção do progresso atingido pela moderna crítica histórica aceitando os diversos exemplos fornecidos por Seignobos de autores que utilizaram afirmações das fontes sem desconfiar de testemunhos tidos como verídicos e ressaltou: "Não deve haver, pois, caráter exterior de um documento que dispense a crítica. Repetimo-lo: é preciso procurar saber o que o autor realmente acreditava porque pode não ser sincero ou talvez se tenha enganado". ${ }^{57}$ É importante a ênfase dada por Taunay a esse ponto do livro Introdução e, portanto, ao cerne dessa concepção que contrapõe verdade e mentira. O que se acompanha passo a passo, nos dois textos, é a apresentação do desenvolvimento da concepção moderna de verdade. ${ }^{58}$

O tom da conferência, apresentada aos iniciantes nos estudos históricos em 1911 na cidade de São Paulo, é o de um trabalho "árduo e demorado" que se justifica pela busca da verdade, uma verdade que "pretende se relacionar com os homens não mais em função de seus valores, dos debates éticos que eles propiciam, mas apenas pela preocupação em se verificar, quando e onde elas efetivamente existiram". ${ }^{59}$ Portanto, importa compreender essa concep-

\footnotetext{
${ }^{55}$ TAUNAY, Afonso de E. Os princípios gerais da moderna crítica histórica..., op. cit., p. 330. ${ }^{56}$ Ibidem, p. 332.

${ }^{57}$ TAUNAY, Afonso de E. Os princípios gerais da moderna crítica histórica..., op. cit., p. 333. 58 “[...] o exame crítico da tradição passou de relativo, na concepção clássica, a absoluto, na moderna. Antes, preservava-se uma parcela da memória, aquela que parecia razoável, plausível aos ouvidos contemporâneos, deixando-se o resto de lado. Agora, tudo o que vem do passado começa a ser olhado com desconfiança, submetido a um contínuo e meticuloso esquadrinhamento, num esforço que demanda tanta minúcia e erudição que termina por converter o historiador em um especialista, em alguém cujo trabalho se caracteriza pela prática de um certo método, chave da verdade e da mentira, acessível apenas depois de árduo e demorado aprendizado". ARAUJO, Ricardo Benzaquen. Ronda noturna: narrativa, crítica e verdade em Capistrano de Abreu. Estudos Históricos. Rio de Janeiro, $\mathrm{n}^{\circ}$ 1, 1988, p. 31.

${ }^{59}$ ARAUJO, op. cit., p. $30-31$.
} 
ção de verdade e os procedimentos metodológicos derivados dela em relação dinâmica com o cotidiano de produção dos textos de Taunay que, claramente, foram informados pelo método proposto por Langlois e Seignobos e por outras referências e circunstâncias que serão compreendidas adiante. No entanto, afirmar que Taunay se inspirou nas diretrizes desse método histórico não significa dizer que ele tenha aplicado todos os procedimentos do método em cada passo de sua produção, o que talvez nem mesmo os próprios autores da Introdução aos estudos históricos tenham feito, mas sim que ele foi informado por esses princípios e, sobretudo, motivado pela busca da "verdade moderna".

Ao realizar essa busca da verdade expressa no documento o historiador deveria considerar, segundo Taunay, uma série de circunstâncias que poderiam influenciar o autor do documento já estabelecido pela crítica de procedência. Portanto, era preciso realizar um inquérito dessa testemunha para saber se ela observou o fato narrado e qual posição ocupou nessa observação. Entretanto, outras questões se incorporavam a esse questionário, pois mesmo tendo "observado o fato da melhor posição", o autor podia mentir ou não conseguir ocultar a simpatia ou antipatia por um grupo de homens, ou talvez fizesse afirmações para "adular o público", ou ainda, mesmo sem intenção, fosse tomado por predileções literárias e estéticas que tivessem "deformado os fatos para os adaptar à sua concepção do belo". ${ }^{60}$

A “desconfiança metódica” empregada na audição das testemunhas, apresentada por Seignobos, foi literalmente exposta por Taunay na conferência e a descoberta do fato foi concluída da seguinte forma:

Examinadas todas essas diversas condições ainda averiguará o crítico, tratando da sua documentação, se os fatos relativos às afirmações são de natureza a tornar a mentira pouco provável ou a fazer com que o erro também seja pouco provável e ainda, que as declarações só correspondem a uma perfeita exatidão. A análise crítica critica concepções e afirmações acompanhadas de notas acerca da probabilidade da exatidão dos acon-

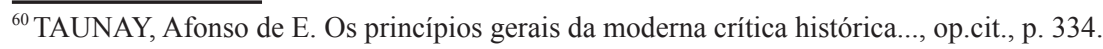


tecimentos afirmados. Dela devem surgir os fatos históricos particulares com os quais a ciência se construirá. ${ }^{61}$

A crítica interna encerra-se nesse ponto da análise e dá lugar às “operações sintéticas" - terceiro livro da obra Introdução aos estudos históricos. Essas operações foram apresentadas como fundamentais diante da confusão de materiais coletados. Taunay afirmou que, como nas demais ciências, o historiador deveria proceder por partes e estabelecer questões. Ressaltou ainda que, quanto aos atos dos homens, um rol de questionamentos eram necessários para definir suas motivações, pois muito "dessemelhantes são as coisas do passado das que vimos e vemos". ${ }^{62}$ Ciente disso, o historiador deveria se libertar do seu ponto de vista moderno e aceitar que "os séculos transformam fundamentalmente o conjunto de ideias que formam o caráter nacional ou o caráter de uma época", ${ }^{63}$ portanto "imparcialmente" o historiador deveria tratar do tema que era relevante para a época e não aquele que se apresentasse como significativo para ele no presente. Taunay citou como exemplo várias atitudes que aos "olhos modernos" poderiam parecer injustificáveis, mas que para a época era a única atitude possível. Em todos os exemplos os acontecimentos foram explicados por meio de um sentido de inevitabilidade.

Nas primeiras obras que escreveu a respeito da história paulista, Taunay imprimiu essa visão de uma História com um sentido definido e destacou a inevitabilidade do crescimento e da projeção da cidade de São Paulo. A narrativa dos "pobríssimos primórdios" da cidade de São Paulo foi conduzida para mostrar como foram heroicos os primeiros anos da "metrópole hodierna do Sul" ${ }^{64}$ Nessas obras as "dessemelhanças" entre passado e presente foram tratadas, principalmente, para argumentar a contraposição entre a vida quinhentista de São Paulo "tão rudimentar e a existência da opulenta capital do século XX, cheia de convicção na magnitude do porvir". ${ }^{65}$ As comparações eram possíveis, pois segundo sua concepção de História, havia a necessidade de um esforço construtivo diante dos "fatos históricos fornecidos pelos documentos". Portanto, se, por um lado, "não há história sem documentos", por outro lado os docu-

\footnotetext{
${ }^{61}$ Idem.

${ }^{62}$ Idem.

${ }^{63}$ TAUNAY, Afonso de E. Os princípios gerais da moderna crítica histórica..., op. cit.

${ }^{64}$ TAUNAY, Afonso de E. São Paulo no século XVI..., op.cit., p. 202.

${ }^{65}$ Ibidem, p. 202.
} 
mentos "não são o bastante para ocupar a composição, há claros a preencher" ${ }^{66}$ Na composição de seus estudos, Taunay relatou esse problema diversas vezes, queixando-se de que a fonte não tratava de alguma questão adequadamente e, portanto, cabia a ele inferir e preencher as lacunas:

Não nos deixam as Atas uma impressão exata do que foi a vida financeira das municipalidades quinhentistas de São Paulo, quanto à sua economia interna, arrecadação de impostos e estabelecimento do sistema tributário. Uma ou outra referência obscura, sumária e pitoresca, podemos respigar, relativa a esse assunto capital. [...] Torna-se muito difícil fazer-se uma ideia dos recursos monetários das primeiras câmaras paulistanas. Pelas alusões das Atas deduz-se que as contribuições das coimas ou direitos sobre o gado e a "renda do verde" constituíam as duas principais bases do orçamento municipal paulistano quinhentista. ${ }^{67}$

A concepção de História defendida por Langlois e Seignobos não ficou sem adversários. Os autores franceses apresentaram a questão da seguinte maneira:

Podemos, pois, considerar os fatos históricos sob dois aspectos opostos: ou naquilo que têm de individual, de particular, de passageiro, ou naquilo que têm de coletivo, de geral, de duradouro. No primeiro caso, a história se apresenta como a narração contínua dos acidentes que ocorreram com os homens do passado; no segundo, ela constitui um quadro dos hábitos sucessivos da humanidade. Neste campo travou-se na Alemanha, principalmente, a batalha entre os partidários da história da civilização (kulturgeschichte) e os historiadores de profissão, que permaneceram fiéis à tradição da Antiguidade; na França, houve luta entre a história das instituições, dos costumes e das ideias e a história política, apelidada com desdém pelos seus adversários “a história batalha”.[...] Não temos que tomar partido nessa controvérsia. A construção histórica completa pressupõe o estudo dos fatos sob os dois aspectos. ${ }^{68}$

Langlois e Seignobos, apesar de afirmarem que não deviam tomar partido em relação às duas opções de escrita da história, — de um lado, a história política, chamada pelos críticos de história batalha, de outro lado, a história

\footnotetext{
${ }^{66}$ TAUNAY, Afonso de E. Os princípios gerais da moderna crítica histórica..., op. cit., p. 339.

${ }^{67}$ TAUNAY, Afonso de E. São Paulo nos primeiros anos..., op. cit., p. 90.

${ }^{68}$ LANGLOIS, Ch. V.; SEIGNOBOS, Ch., op. cit., p. 165-166.
} 
da civilização preocupada com os costumes e com as ideias - apresentaram a "narração dos acontecimentos" empreendida pela história política e administrativa como uma das possibilidades do "fazer história" e foram fortemente atacados, especialmente, por Lucien Febvre e Marc Bloch. ${ }^{69}$

Diante do impasse entre a história política e a história da civilização, Afonso de Taunay ${ }^{70}$ primeiramente apresentou a questão reproduzindo literalmente as posições apresentadas no livro Introdução aos estudos históricos. No entanto, pouco antes de terminar sua conferência ele retomou tal questão e apresentou elementos fundamentais para a defesa do tipo de História que escreveu nos anos posteriores àquela conferência:

Com o século XVIII abriu-se nova era: principiou-se a estudar a história dos hábitos dos homens e não mais unicamente a dos acontecimentos. Já antes de 1800 surge, pela primeira vez, a expressão: história da civilização. [...] Com o movimento romântico procuraram os historiadores comover o público; aparece com sir Walter Scott o romance histórico, e todos os autores julgam necessário reproduzir os fatos com a comoção do espectador. "Thierry, ao falar-nos de Clovis, diz Michelet, louvandoo muito aliás, transmite as vibrações da França recentemente invadida". Até 1850, pode dizer-se, ficou a história sendo, para o público e para os historiadores, um gênero literário; desta data em diante, paulatinamente, se desenhavam as linhas gerais da moderna concepção histórica. Dia-adia avultando, surgiram as monografias mais completas, mais rebuscadas quanto à documentação. Entre os trabalhos de caráter geral apareceram novos manuais, para todos os ramos especiais da história da civilização,

\footnotetext{
${ }^{69}$ FEBVRE, Lucien. Combates pela História. $3^{\text {a }}$ ed. Lisboa: Editorial Presença, 1989. (Os textos que compõem o livro foram produzidos nas primeiras décadas do século XX e reunidos pelo autor em 1949); BLOCH, Marc. Apologia da história ou O ofício do historiador. Rio de Janeiro: Jorge Zahar Ed., 2001. (Marc Bloch morreu fuzilado pelos alemães em 16 de junho de 1944 deixando inacabado o texto que somente foi publicado por Lucien Febvre em 1949.)

${ }^{70}$ Aqui não se afirma que Taunay conhecia as críticas apresentadas por Lucien Febvre e Marc Bloch, pois não há nenhuma referência que autorize tal assertiva. $\mathrm{O}$ impasse apresentado por Taunay partiu, ao que tudo indica, exclusivamente das informações expostas no texto de Langlois e Seignobos e de seus referenciais da historiografia brasileira desenvolvida no período.
} 
maravilhosa condensação dos esforços de vidas inteiras de numerosos colaboradores $[\ldots]^{71}$

Neste trecho da conferência, Taunay fez um resumo do capítulo V do livro III da Introdução, intitulado "Exposição", e conferiu relevo, como em outras passagens, aos argumentos que lhe interessavam. Um destaque interessante foi dado à citação que Michelet faz de Thierry, ${ }^{72}$ pois no texto de Langlois e Seignobos esta referência foi utilizada para se contrapor à "história científica" e no texto de Taunay ela apareceu como se "as linhas gerais da moderna concepção histórica" tivessem se desenhado paulatinamente ao lado ou juntamente com essa possibilidade de história sem, portanto, a clara oposição que os autores da Introdução apresentaram. Outro ponto importante é a história da civilização que na Introdução foi apresentada como uma das possibilidades de história e, na conferência, Taunay a ressaltou como a história que se produzia no momento.

A primeira ênfase talvez tenha se dado porque o autor da conferência não acreditasse que o romance histórico não pudesse ser pautado em documentos criticados metodicamente e, portanto, pudesse dizer a verdade dos fatos. No ano anterior àquela conferência proferida em 1911, ele havia publicado um romance histórico intitulado Crônica do tempo dos Filipes, ${ }^{73}$ o qual, poucos meses após essa aula inaugural apresentada na Faculdade de São Bento, foi proposto para a avaliação de ingresso de Taunay no Instituto Histórico e Geográfico de São Paulo e no Instituto Histórico e Geográfico Brasileiro. A segunda ênfase, bastante clara em sua obra, era necessária para Taunay, pois nos "balanços historiográficos" produzidos por ele, em 1914, 1931 e 1934, a história da civilização, chamada por ele de história dos costumes, foi apresentada como a história que deveria ser escrita no Brasil naquele momento.

\footnotetext{
${ }^{71}$ TAUNAY, Afonso de E. Os princípios gerais da moderna crítica histórica..., op. cit., p. 342-343 (grifo nosso).

72 “Augustin Thierry é um dos principais representantes dessa geração [romântica] que se vê como iniciadora de uma nova aventura e encarna a vontade de criar uma nova história da França: 'Ainda não temos História da França', escreve ele em 1820. Para existir, esta deverá passar por um deslocamento de olhar, que não se contenta em observar as esferas dirigentes, mas reavalia a situação da gente humilde, dos anônimos: 'Falta-nos a história dos cidadãos, a história dos súditos, a história do povo"”. DOSSE, François. A história à prova do tempo..., op. cit,. p. 14. Afonso de Taunay quando defende a escrita de uma História dos costumes se pauta em muitos desses argumentos apresentados por Thierry, portanto sua visão em relação à chamada "história romântica" francesa é diferente daquela exposta por Langlois e Seignobos.

${ }^{73}$ TAUNAY, Afonso de E. Crônica do tempo dos Filipes. Tours: Imprimerie E. Arrault et Cie, 1910.
} 
Portanto, as concepções de Taunay fundadas em referenciais ligados à sua trajetória de homem de letras formado no Brasil se impuseram nesse ponto da conferência diante das diretrizes propostas por Langlois e Seignobos. Os autores franceses visavam criticar uma história que alcançou grande prestígio de público na França, mas que, segundo eles, não se constituiu das "formas científicas de exposição histórica". ${ }^{74}$

Afonso de Taunay não se opôs à forma de exposição vigente no cenário de escrita da história em São Paulo no período. A propósito, ele foi um dos principais autores a utilizar-se do estilo épico de escrita para a narrativa do tema das Bandeiras. ${ }^{75}$ Taunay acreditava que os procedimentos apresentados por Langlois e Seignobos para a escrita de história sob princípios modernos não excluíam a forma romanceada. Taunay fez uso de uma das “deformações dos fatos históricos", condenadas pelos autores da Introdução, ou seja, a "deformação épica que embeleza a narração, acrescentando-lhe pormenores pitorescos em que a aparente precisão de minúcias dá a ilusão de verdade", ${ }^{76}$ mas nem por isso deixou de acreditar nos procedimentos de crítica das fontes e, especialmente, não abandonou a busca da verdade moderna. Quando perguntado, em 1930, por um amigo a respeito do método histórico mais adequado à História, Taunay respondeu:

Sobre as correntes da moderna crítica histórica recomendo-lhe muito o livro de Langlois e Seignobos que tive o ensejo de resumir numa conferência que se acha publicada no tomo XVI da Revista do Instituto Histórico e Geográfico de São Paulo. Aí neste meu trabalho há também uma súmula de apreciações feitas sobre as ideias de outros autores e a respeito dos mesmos assuntos. ${ }^{77}$

Esta carta acentua a importância da conferência apresentada nesse capítulo para a compreensão das concepções de História de Taunay, pois após quase vinte

\footnotetext{
${ }^{74}$ LANGLOIS, Ch. V.; SEIGNOBOS, Ch., op. cit., p. 212. Para a compreensão da escrita da História no século XIX na França, cf. HARTOG, François. O século XIX e a história: o caso Fustel de Coulanges. Rio de Janeiro: Editora UFRJ, 2003; Idem. Michelet, a história e a "verdadeira vida". Agora. Santa Cruz do Sul, v. 11, no. 1, p. 13-20, jan./ jun. 2005; GUIMARÃES, Manoel Luiz Salgado. Entre amadorismo e profissionalismo: as tensões da prática histórica no século XIX. In: Topoi, Rio de Janeiro, p. 184-200, dezembro de 2002.

${ }^{75} \mathrm{Cf}$. FERREIRA, op. cit.

${ }^{76}$ LANGLOIS, Ch. V.; SEIGNOBOS, Ch., op. cit., p. 120.

${ }^{77}$ Carta de Afonso de Taunay a João Lourenço Rodrigues, São Paulo, 31 de janeiro de 1930, APMP/ FMP ( $1^{\mathrm{a}}$ entrada), pasta 138. João Lourenço Rodrigues nasceu em Tatuí, em 8 de janeiro de 1869. Foi aluno da Escola Normal de São Paulo e após a formatura tornou-se inspetor escolar, em 1905, e
} 
anos aquelas referências ainda eram consideradas por ele como os princípios básicos da pesquisa histórica.

No entanto, não é somente a citação da obra de Langlois e Seignobos nesta carta que mostra a relevância que esses procedimentos assumiram na fundamentação da escrita da história de Taunay nem, contudo, a confirmação de que resumir essa obra pode ser elemento suficiente para classificá-lo como um historiador metódico tal e qual os historiadores franceses, especialmente porque esta é uma definição cujo conteúdo seria de difícil composição, pois até para os historiadores franceses ela tem sido alvo de releituras e revisão. ${ }^{78}$

Portanto, este método foi uma das referências que informaram as composições historiográficas de Taunay, um metódico à brasileira que confrontou os procedimentos de análise interna e externa do documento, bem como as definições quanto à melhor história a ser escrita, ditadas por Langlois e Seignobos com outro universo de produção, o brasileiro, e, assim, rearranjou estes elementos de acordo com as possibilidades apresentadas pela escrita da história no Brasil.

\section{0 orientador da história da "conquista do Brasil pelos brasileiros"79}

No final do século XIX, as diretrizes apontadas por Afonso de Taunay já não eram exatamente uma novidade entre os letrados brasileiros dedicados aos estudos históricos, pois elas haviam sido apresentadas por aquele que podemos chamar de mestre de muitos autores das primeiras décadas do século XX. Em 1878, Capistrano de Abreu, ao avaliar os estudos históricos em um texto especialmente elaborado para a homenagem póstuma a Francisco Adolfo de Varnhagen (1816-1878), apresentou considerações a respeito dos escritos históricos produzidos durante o século XIX e estabeleceu os rumos que a disciplina deveria tomar, ou seja, delimitou objetivos e desafios para as gerações seguintes. Dessa forma, ele esclareceu aquilo que deveria ser priorizado, tanto os temas quanto a metodologia. Esse diagnóstico muito influenciou os estudos apresentados por Taunay nas conferências aqui já mencionadas.

posteriormente, foi Diretor de Ensino. A partir de 1908, viajou pela Europa e Estados Unidos com o intuito de aprender como era o ensino em outros países. Morreu em 20 de janeiro de 1954.

${ }^{78}$ PROST, Antoine. Charles Seignobos revisité. In: Vingtième Siècle. Revue d’histoire. Paris, $\mathrm{n}^{\circ}$ 43, p. 100-118, jul./set. 1994; PONS, Anaclet e SERNA, Justo. Apologia de la história metódica. In: Pasajes. Revista de pensamiento contemporâneo. Valência, Espanha, $n^{\circ}$ 16, p. 128-136, invierno de 2005. ${ }^{79}$ TAUNAY, Afonso de E. São Paulo no século XVI..., op.cit., p. 202. 
O Necrológio de Francisco Adolfo de Varnhagen, visconde de Porto Seguro ${ }^{80}$ foi publicado no Jornal do Commercio entre 16 e 20 de dezembro de 1878 , sendo posteriormente reproduzido em Apenso à História geral do Brasil em sua quarta edição e na Revista do Instituto Histórico e Geográfico Brasileiro de 1916; tamanha divulgação tornou esse texto ponto de partida ou passagem obrigatória das análises a respeito de Varnhagen e Capistrano de Abreu ou da produção historiográfica do Oitocentos. ${ }^{81}$

Nesse texto, ao percorrer a trajetória de Varnhagen, Capistrano delineia aos poucos os elementos da profissão. Começa pela motivação primeira, a atração pelo desconhecido, "a paixão pelos problemas não solvidos" $\$ 2$ que encaminharia o elogiado para o "terreno fugidio das dúvidas e das incertezas" por onde caminhava "bravo e sereno, destemido bandeirante à busca da mina de ouro da verdade". ${ }^{83}$ Essa imagem do bandeirante que busca desbravar a verdade nas minas escondidas da história aparece reiteradas vezes nos textos escritos nas primeiras décadas do século XX.

É importante conhecer as lições que Capistrano dispensava aos escritores com os quais se correspondia, pois poucos escritos escaparam de suas críticas,

${ }^{80}$ ABREU, Capistrano de. Necrológio de Francisco Adolfo de Varnhagen, visconde de Porto Seguro. Ensaios e Estudos (Crítica e História). $1^{\mathrm{a}}$ série, $2^{\mathrm{a}}$ ed. Rio de Janeiro: Civilização Brasileira; Brasília, INL, 1975.

${ }^{81}$ Cf. RODRIGUES, José Honório. História e historiadores do Brasil. São Paulo: Fulgor, 1965; Idem. História e Historiografia. Petrópolis, Rio de Janeiro: Editora Vozes, 1970; LAPA, José Roberto do Amaral. A história em questão: Historiografia brasileira contemporânea. Petrópolis, Rio de Janeiro: Vozes, 1976; CANABRAVA, Alice. Apontamentos sobre Varnhagen e Capistrano de Abreu. Revista de História. São Paulo, USP, 18 (88), out/dez, 1971; ARAÚJO, Ricardo Benzaquen. Ronda noturna: narrativa crítica e verdade em Capistrano de Abreu. Estudos Históricos. Rio de Janeiro, n 1, p. 28-54, 1988; WEHLING, Arno. A invenção da História: estudos sobre o historicismo. Rio de Janeiro: Editora Central da Universidade Gama Filho; Niterói: Editora da UFF, 1994; Idem. Estado, história, memória: Varnhagen e a construção da identidade nacional. Rio de Janeiro: Nova Fronteira, 1999; REIS, José Carlos. As identidades do Brasil: de Varnhagen a FHC. $3^{\text {a }}$ ed. Rio de Janeiro: Editora FGV, 2000; PEREIRA, Daniel Mesquita. Descobrimentos de Capistrano. A história do Brasil "a grandes traços e largas malhas". Tese de doutorado, Programa de Pós-Graduação em História Social da Cultura, Pontifícia Universidade Católica do Rio de Janeiro, 2002; GONTIJO, Rebeca. História e historiografia nas cartas de Capistrano de Abreu. História (São Paulo). v. 24, p. 159-185, 2005; GONTIJO, Rebeca. O intelectual como símbolo da brasilidade: o caso Capistrano de Abreu. In: ABREU, Martha; SOIHET, Rachel; GONTIJO, Rebeca (org.). Cultura política e leituras do passado: historiografia e ensino de história. Rio de Janeiro: Civilização Brasileira, 2007, p. 309-327; OLIVEIRA, Maria da Glória. Crítica, método e escrita da história em João Capistrano de Abreu (1853-1927). Dissertação de mestrado, Programa de Pós-Graduação em História, Universidade Federal do Rio Grande do Sul.

${ }^{82}$ ABREU, Capistrano de. Necrológio de Francisco Adolfo de Varnhagen ..., op. cit, p. 82.

${ }^{83}$ Ibidem, p. 83. 
correções e deboches. Apesar de pedir aos amigos e conhecidos para não tornálo um mestre, muitos autores das primeiras décadas do século XX definiram-se discípulos de Capistrano. Naquelas décadas de 1910 e 1920, ele era uma referência quase unânime, pelo menos para os pesquisadores de diversas regiões do Brasil vinculados de alguma maneira, ora por meio dos institutos ora por contatos pessoais, ao universo de produção historiográfica de São Paulo e Rio de Janeiro. Esses autores relataram em diversos escritos suas dívidas para com Capistrano, o grande "orientador" do período.

Mas voltando ao texto em que tratou de Varnhagen, traçando seus primeiros aprendizados e, especialmente, suas inclinações, Capistrano salientou que, no "cultivo da ciência, não era o esmero das observações, a beleza do método e das experiências, a força e o alcance das teorias e generalizações" ${ }^{\prime 4}$ que mais interessavam a Varnhagen, mas incitavam-o a aplicação que seus conhecimentos poderiam ter para o país. A apreciação realizada por Capistrano nesse trecho, assim como no restante do texto, trazia as aspirações dele, aquilo que ele acreditava ser mais importante, apresentava nessas páginas o seu projeto de escrever uma história do Brasil com as teorias que nesse momento o encantavam, o método e o rigor das observações estavam ali apontados e por diversas vezes foram salientadas em suas orientações aos autores principiantes.

Todavia, mesmo sem o alcance das teorias e generalizações, havia algo que essa aplicação realizara e que Capistrano não somente admirava como também sobre a qual empreendera esforços durante grande parte de sua vida. A dedicação de Varnhagen resultou na correção, anotação e descoberta de autoria de obras fundamentais para o conhecimento da história do Brasil. O primeiro trabalho impresso tratava-se da descoberta de autoria do livro de Gabriel Soares de Sousa. Nesse texto, Varnhagen não cuidou apenas de "desvendar" o nome do autor, mas, sobretudo, "corrigiu erros, identificou as espécies biológicas e determinou as posições geográficas". ${ }^{85}$ Tarefa semelhante foi realizada pelo próprio Capistrano junto à História geral do Brasil de Varnhagen. ${ }^{86}$ Varnhagen, segundo a avaliação de Capistrano, produziu o "efeito de uma revelação",

\footnotetext{
${ }^{84}$ ABREU, Capistrano de. Necrológio de Francisco Adolfo de Varnhagen ..., op. cit, p. 83.

${ }^{85}$ Ibidem, p. 83.

${ }^{86}$ A respeito do trabalho de anotação realizado por Capistrano de Abreu e Rodolfo Garcia na História geral do Brasil de Varnhagen, cf: OLIVEIRA, Maria da Glória. A anotação à História geral do Brasil: conversações ao pé de página. In: Crítica, método e escrita da história em João Capistrano de Abreu (1853-1927), op. cit.
} 
abrindo um "mundo novo às investigações de todos aqueles que se ocupavam de nossos anais". 87

Por mais inovador que se apresentasse tal intento de correção e complementação da obra de Gabriel Soares de Sousa, o trabalho realizado por Varnhagen logo seria superado por novos estudos. Essa era a sina do ofício, segundo Capistrano: a partir da investigação de cartórios e bibliotecas e da consequente descoberta de novos acontecimentos, os escritos perdiam sua atualidade e eram superados pelos posteriores.

No entanto, ainda caberia a Varnhagen um grande contributo nesse caminho do conhecimento histórico narrado por Capistrano. Após se dedicar à sina do historiador "que investiga cartórios, compulsa as bibliotecas dos mosteiros, examina os padrões de outras eras, colhe glossários e tradições, e nas localidades comenta e verifica os dizeres de Taques e frei Gaspar da Madre de Deus", 88 Varnhagen publicou sua História geral do Brasil com a coleta de um número de fatos e documentos maior do que todos aqueles que o precederam. E como indicava a forma de se escrever história no período, a busca interminável levou a uma segunda edição acrescida ainda de novos dados conseguidos a partir de visitas às províncias e explorações de roteiros históricos.

Capistrano reconheceu os méritos de Varnhagen, contudo, ele próprio, naquele momento, tinha o projeto de escrever uma nova história. ${ }^{89}$

Ele poderia escavar documentos, demonstrar-lhes a autenticidade, solver enigmas, desvendar mistérios, nada deixar que fazer a seus sucessores no terreno dos fatos: compreender, porém, tais fatos em suas origens, em sua ligação com fatos mais amplos e radicais de que dimanam; generalizar as ações e formular-lhes teoria; representá-las como conse-

\footnotetext{
${ }^{87}$ Ibidem, p. 84.

${ }^{88}$ ABREU, Capistrano de. Necrológio de Francisco Adolfo de Varnhagen ..., op. cit, p. 84.

${ }^{89}$ Cf. especialmente o capítulo 1 intitulado "Quatro séculos depois" de PEREIRA, op. cit.; MATTOS, Ilmar Rohloff. Capítulos de Capistrano. Localizado no portal Modernos descobrimentos. $<$ http://www.modernosdescobrimentos.inf.br/desc/capistrano/capituloscapistrano.htm>; AMED, Fernando José. As cartas de Capistrano de Abreu: sociabilidade e vida literária na belle époque carioca. São Paulo: Alameda, 2006; DIEHL, Astor Antônio. O que é História? Sistemas de referência e narrativa. Capistrano de Abreu e o moderno sentido para a historiografia brasileira. Ágora. Santa Cruz do Sul, v. 11, nº 1, p. 49-77, jan./ jun. 2005.
} 
quências e demonstração de duas ou três leis basilares, não conseguiu, nem consegui-lo-ia. ${ }^{90}$

Os elementos foram encontrados e reunidos por Varnhagen, faltava alguém para elevar o edifício, alguém que conhecesse os métodos novos e fizesse uso dos instrumentos poderosos que a ciência disponibilizava. Nesse momento, Capistrano acreditava nesse poder do método, na teoria da evolução e conclamava a vinda de alguém capaz de mostrar a "unidade que ata os três séculos" de história do Brasil e de arrancar "das entranhas do passado o segredo angustioso do presente" para libertar a História "do empirismo crasso". ${ }^{91}$

Quatro anos mais tarde, Capistrano publicou na Gazeta de Notícias do Rio de Janeiro o texto Sobre o visconde de Porto Seguro ${ }^{92}$ no qual já se percebe uma mudança. Enquanto naquele texto insistia na ideia de que "por toda parte pululam materiais e operários; não tardará talvez o arquiteto", ${ }^{93}$ neste já afirmava que a história do Brasil não seria escrita tão cedo. "Agora o que se precisa é de monografias conscienciosas". ${ }^{94}$

Anos mais tarde ele ainda queria compreender o Brasil, mas como ele mesmo afirmou, as leis não o encantavam tanto, acreditava que estávamos em um momento em que muito havia por ser descoberto para que se pudesse conhecer o Brasil e foi esse Capistrano que escreveu Capítulos de história colonial ${ }^{95}$ obra que ele avaliava "repleta de lacunas, assemelhando-se menos a um edifício e muito mais a uma tapera [...] Confortava-lhe a certeza de ter feito germinar uma flor: a história do Brasil". ${ }^{96}$

No entanto, antes mesmo de redefinir suas opiniões a respeito dos caminhos da história no início do século, a perspectiva historiográfica de Capistrano de Abreu representou elemento decisivo para as escolhas de Afonso de Taunay e de um grande rol de escritores do período. Taunay conviveu com Capistrano entre 1884 e 1885, quando ele foi "explicador particular" de seu tio materno Francisco José Teixeira Leite e depois, entre 1988 e 1889, quando os pais de

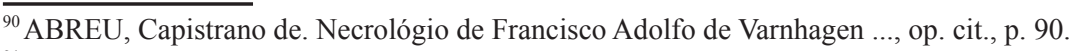

${ }^{91}$ Ibidem, p. 91.

${ }^{92}$ ABREU, Capistrano de. Sobre o visconde de Porto Seguro ..., op.cit.

${ }^{93}$ ABREU, Capistrano de. Necrológio de Francisco Adolfo de Varnhagen ..., op. cit., p. 91.

${ }^{94}$ ABREU, Capistrano de. Sobre o visconde de Porto Seguro..., op. cit., p. 139.

${ }^{95}$ ABREU, Capistrano de. Capítulos de história colonial (1500-1800). Belo Horizonte: Itatiaia; São Paulo: Publifolha, 2000.

${ }^{96}$ MATTOS, Ilmar. op. cit, p. 5.
} 
Taunay resolveram que ele se apresentaria perante as bancas de preparatórios para prestar os exames de Corografia e História do Brasil do Colégio Pedro II e, portanto, precisava de professores para lhe ensinar os conteúdos dessas disciplinas. Para as aulas de Corografia foi contratado o geógrafo Alfredo Moreira Pinto e para as lições de História do Brasil, Capistrano de Abreu. Foi mais tarde, em 1902, durante uma visita a Capistrano que Taunay confessou-lhe o desejo de escrever história. Ao ouvir a assertiva de seu jovem discípulo, o mestre lhe sugeriu que se dedicasse ao estudo da história das Bandeiras.

Esse acontecimento, considerado pelo próprio Taunay como um ato fundador em sua trajetória, foi narrado por ele aos seus pares intelectuais tanto em cartas quanto, especialmente, em discursos de ingresso ou consagração institucional. Foi um episódio contado diversas vezes para traçar sua trajetória intelectual e definir sua inserção historiográfica. Podemos acompanhá-lo em 1939 no discurso de posse da Presidência Honorária do Instituto Histórico e Geográfico de São Paulo:

— Se você está em São Paulo e quer escrever história, — aconselhou-me certa vez o meu querido e saudosíssimo mestre Capistrano de Abreu, faça uma coisa: estude as Bandeiras.

— Mas, isto é muito trabalhoso demais, — objetei-lhe — A vida de um homem não dá para tanto.

— Você ainda é moço e quem não tem coragem não amarra canhembora no mato, segundo afirma um prolóquio de minha terra, - retrucou-me o mestre cearense, em rude comparação de seu feitio de sinceridade absoluta.

— Preferiria algum assunto mais fácil, menos extenso e mais à mão, por exemplo o período dos capitães-generais.

Aí se agastou o autoritário amigo, apaixonado da franqueza e da ausência de rebuços:

— É mais fácil e mais à mão, com efeito! E assim também mais facilmente conseguirá você dar uma demonstração de rara ininteligência! Deixará um episódio máximo dos nossos anais, máximo e quase virgem na consolidação de seus fastos, para cuidar de uma relação quase sempre 
de meros atos burocráticos de um período de depressão e decadência. Parabéns pelo brilhantismo da escolha!

Deixou-me tão rude franqueza abalado ao despedir-me, em meados de 1902, da visita feita no Rio de Janeiro a quem tão categoricamente se exprimia. ${ }^{97}$

A conversa narrada daria origem à carta, fartamente citada pelos biógrafos de Afonso de Taunay, em que Capistrano reafirma as opiniões expostas pessoalmente ao discípulo. Dificilmente ele poderia concordar com a intenção de Taunay, pois talvez nessa época não o considerasse incapaz, como avaliava dois historiadores contemporâneos cujos nomes foram omitidos da transcrição publicada por Taunay nos jornais e também no discurso de posse em que tratou do assunto.

A sua ideia de escrever uma história dos capitães-generais de S. Paulo é simplesmente infeliz. Que lembrança desastrada a de preferir um período desinteressante, quando a grande época dos paulistas é o século XVII! Deixe este encargo ao... ou ao... Isto lhes vai a calhar. Que encham as páginas da Revista com tão desenxabido assunto.

Reserve você para si o melhor naco, deixe os miúdos para quem deles gostar. ${ }^{98}$

Quando escreveu essa carta Capistrano estava prestes a iniciar a redação de Capítulos de história colonial, encomendado pelo Centro Industrial do Brasil em 1905. Esta seria a concretização de um projeto idealizado ainda nas décadas finais do século XIX. Nos Capítulos a herança ibérica e a obra administrativa da coroa imperial que ocupavam a primeira cena na história político-administrativa e biográfica realizada por Robert Southey e por Francisco Adolfo de Varnhagen deram lugar aos indígenas, à miscigenação, aos costumes, ao clima e à conquista do sertão. Caracterizado como revisionista e criador de um mundo novo, ${ }^{99}$ redescobridor do Brasil, ${ }^{100}$ símbolo da influência cientificista, ao menos em sua primeira fase,${ }^{101}$ representante de uma nova concepção de verdade na

\footnotetext{
${ }^{97}$ TAUNAY, Afonso de E. Discurso de posse na Presidência Honorária do Instituto. RIHGSP, v. 37, 1939, p. 10-11.

${ }^{98}$ Carta de Capistrano de Abreu a Afonso Taunay, dia de s. Bertoldo e s. Columbado [1904?], In: ABREU, Capistrano de. Correspondência de Capistrano de Abreu. volume 1; edição organizada e prefaciada por José Honório Rodrigues. $2^{\text {a }}$ ed. Rio de Janeiro: Civilização Brasileira; Brasília: INL, 1977, p. 276. Para um estudo detalhado da correspondência de Capistrano de Abreu, cf. AMED, op. cit.

${ }^{99}$ RODRIGUES, José Honório. História e historiadores do Brasil. São Paulo: Fulgor, 1965.

${ }^{100}$ REIS, José Carlos, 2000, op.cit.

${ }^{101}$ WEHLING, Arno, 1994, op. cit.
} 
historiografia brasileira, ${ }^{102}$ aquele que implementou e renovou a moderna historiografia brasileira, ${ }^{103}$ ora positivista, ora historicista, Capistrano de Abreu, ao se interessar pelo método crítico das ciências do espírito, talvez acreditasse que o historiador devesse "reconstituir" a vida integralmente. ${ }^{104}$

Portanto, a ideia de escrever a história dos capitães-gerais apresentada por Taunay a Capistrano naquela conversa de 1902 corroborava as escolhas temáticas de Varnhagen, deixando Capistrano um pouco desapontado. No entanto, instigado e convencido de que poderia ser um caminho promissor, Taunay alterou seus planos e se dedicou à história das Bandeiras. "Comecei a obedecer ao mestre, a me introduzir numa camisa, não de onze, mas de cento e dez varas, que é a ventilação dos fastos biseculares do epos bandeirante", ${ }^{105}$ rememorava Taunay no discurso de posse em que retraçou sua própria trajetória conferindo a Capistrano o lugar de mestre, orientador tanto das escolhas de temas quanto da abordagem de grande parte de sua produção.

No entanto, não foi somente nesse ato inaugural do interesse de Taunay pela história das Bandeiras que Capistrano de Abreu esteve presente. Esse autor acompanhou a composição das obras de Taunay desde princípios do ano de 1900, quando Taunay foi trabalhar em São Paulo e, especialmente, durante as décadas de 1910 e 1920. A leitura da correspondência enviada por Capistrano de Abreu a Taunay permite acompanhar as discussões que permearam a composição tanto de algumas obras de Taunay quanto de Capistrano a respeito do passado brasileiro, bem como é possível compreender os contornos do ambiente intelectual no qual eles estavam inseridos.

Na correspondência, esse "lugar de sociabilidade" privilegiado para se compreender o "pequeno mundo intelectual", ${ }^{106}$ primeiramente publicadas por Taunay no Jornal do Comércio com o acréscimo de notas explicativas e depois editadas por José Honório Rodrigues, sem as notas, foram compartilhadas muitas informações a respeito dos institutos do Rio de Janeiro e de São Paulo, da Biblioteca Nacional, do Museu Paulista e da produção de diversos escritores do

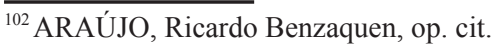

${ }^{103}$ DIEHL, Astor Antônio. A cultura historiográfica brasileira: do IHGB aos anos 1930. Passo Fundo: Ediupf, 1998, p. 52.

${ }^{104}$ REIS, José Carlos, 2000, op.cit.

${ }^{105}$ TAUNAY, Afonso de E. Discurso de posse na Presidência Honorária do Instituto..., op. cit., p. 11. ${ }^{106}$ GOMES, Ângela de Castro (organização, introdução e notas). Em família: a correspondência de Oliveira Lima e Gilberto Freyre. Campinas, São Paulo: Mercado de Letras, 2005 (Coleção Letras em Série).
} 
período. Muitas vezes essas cartas acompanharam artigos trocados para correção, documentos para o preenchimento de lacunas das pesquisas que realizavam, informações a respeito de datas, nomes, acontecimentos e visões conflitantes. Ora como um orientador atento que cobrava o envio das produções para correção, ora como um colega de ofício que pedia ajuda para a realização das pesquisas, Capistrano de Abreu foi um companheiro que dizia não gostar de ser chamado de mestre, como deixou claro em uma carta enviada em princípios de 1900, segundo uma nota de Taunay acrescida na publicação do Jornal do Comércio:

Afonso amigo,

É você teimoso! Já lhe disse várias vezes: nem mestre, nem dr.! Mestre!? Mestre de meninos? Sabe você perfeitamente que doutorei na "academia de xenxém". Não reincida que o caso é de non placet. ${ }^{107}$

No entanto, mesmo com os repetidos pedidos de Capistrano para não ser chamado de mestre, Taunay dizia-se discípulo dele e insistia em vincular-se aos ensinamentos do historiador cearense todas as vezes que traçava sua trajetória ou mesmo, como já foi tratado nesse capítulo, quando buscava apresentar os caminhos da historiografia. Em 1914, Taunay declarou sua intenção de constituir o que ele chamou de "Bandeira do passado"108 e Capistrano de Abreu foi escolhido como o historiador que abriu os caminhos para a constituição dessa perspectiva de estudos da história das Bandeiras com ênfase em uma abordagem da história dos costumes.

"Faltam documentos para escrever a história das Bandeiras", ${ }^{109}$ escreveu Capistrano nos Capítulos em 1907 após ter sugerido o tema para Taunay. "Que mina, e que mina virgem, a dos arquivos que dormiam", ${ }^{110}$ respondeu Taunay. Foi por meio da descoberta destas "minas virgens" que esse discípulo se dedicou à produção da história da "conquista do Brasil pelos brasileiros"111 e publicou em onze

\footnotetext{
${ }^{107}$ Carta de Capistrano de Abreu a Afonso Taunay, sem data. In: ABREU, Capistrano de. Correspondência de Capistrano de Abreu. volume 1; edição organizada e prefaciada por José Honório Rodrigues. $2^{\text {a }}$ ed. Rio de Janeiro: Civilização Brasileira; Brasília: INL, 1977, p. 274.

${ }^{108}$ TAUNAY, Afonso de E. Os quatro primeiros lustros de vida do Instituto..., op. cit.

${ }^{109}$ ABREU, Capistrano de. Capítulos de história colonial (1500-1800)..., op. cit., p. 129.

${ }^{110}$ TAUNAY, Afonso de E. Discurso de posse na Presidência Honorária do Instituto..., op. cit., p. 12.

${ }^{111}$ TAUNAY, Afonso de E. São Paulo no século XVI..., op.cit., p. 202.
} 
volumes a História geral das Bandeiras paulistas e tantos outros volumes a respeito da história do Brasil, de São Paulo, das Bandeiras.

Quando publicou o primeiro desses volumes, Taunay o enviou para Capistrano que, em carta, agradeceu-lhe e enfatizou a importância do tema:

Afonso amigo,

Agradeço-lhe o $1^{\circ}$ volume da História e congratulo-me por ter você dado este primeiro passo num terreno a que ninguém se animara.

Apenas abri as páginas. Não me agradou Colúmbia para designar o país da América Central. [...] parece haver páginas demais quanto aos espanhóis. Isso não chega a ser uma impressão. A leitura será vagarosa; quando discordar de algo, escreverei. ${ }^{112}$

Com o tom de um orientador que se propõe a corrigir os escritos do aluno, Capistrano escreveu durante quase três décadas para Taunay a respeito de diversos livros e artigos respaldando, de certa forma, o sentimento, declarado por Taunay em diversas oportunidades, de orientando ou discípulo do mestre que não queria ser chamado de tal forma, mas a todo o momento, quando solicitado ou não, estava pronto a orientar.

Antes mesmo de se dispor a corrigir o primeiro volume da História geral das Bandeiras paulistas, Capistrano de Abreu já havia orientado os estudos preliminares realizados por Taunay, especialmente as pesquisas a respeito de Pedro Taques. Capistrano representou uma das principais referências para a escrita da história de Afonso de Taunay, segundo ele mesmo reafirmou diversas vezes no decorrer da vida. Um dos textos em que o autor se mostra comovido ao tratar dessa filiação é no artigo "J. Capistrano de Abreu - In memoriam” publicado no terceiro tomo dos Anais do Museu Paulista em 1927 para lembrar sua relação com o mestre e agradecê-lo após seu falecimento naquele ano:

A Capistrano devi assinalados serviços e os mais leais conselhos. Deu-me indicações preciosíssimas sobre muitos e muitos assuntos. Indicou-me opulentas fontes com aquela prodigiosa liberalidade e ausência total de inveja que formavam o fundo do seu íntimo, ao oferecer aos amigos, aos consulentes em geral, a poderosa valia de seu formidável cabedal

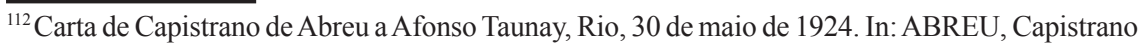
de. Correspondência de Capistrano de Abreu. volume 1; edição organizada e prefaciada por José Honório Rodrigues. 2a ed. Rio de Janeiro: Civilização Brasileira; Brasília: INL, 1977, p. 342.
} 
de conhecimentos. E como se interessava pelo andamento dos trabalhos daqueles a quem estimava! Como desejava que se aperfeiçoassem! Seja-me aqui permitida pública demonstração de reconhecimento para com a generosidade dos seus conselhos, indulgência, o reconforto de sua animação e a lealdade de seus avisos. ${ }^{113}$

Esse texto abriu uma sessão dos Anais dedicada a homenagear Capistrano de Abreu com a reprodução de um discurso de João Pandiá Calógeras (1870-1934) pronunciado no IHGB e um estudo de Vicente Licínio Cardoso (1890-1931) publicado no O Jornal do Rio de Janeiro. Com o intuito de relembrar os quarenta anos de convivência com o "sabedor das coisas do Brasil", ${ }^{114}$ Taunay contou o primeiro contato com o mestre - "Vi-me, na nossa casa das Laranjeiras, no Rio de Janeiro, menino de doze anos, seu aluno de História do Brasil, seu explicando único entusiasmado com as suas lições" - e o último: "Vi-me depois, ao lado de sua rede, no seu humílimo porão solitário, quando já a lutar com a pneumonia dupla que o fazia sufocar, mas não lhe abatia a serenidade e a coragem". ${ }^{115}$

Essas passagens apresentam o lado afetivo compartilhado por esses dois homens durante quatro décadas de convivência profissional e mostram o quanto, em meio a indicações de fontes e livros, correções de textos e conselhos de posturas intelectuais, eles construíram uma amizade e trocaram cartas, afetos, desentendimentos e muitas desaprovações. Estas vinham especialmente de Capistrano que, para não desestimular o jovem aprendiz, amenizava nas críticas diretas e as fazia com o seu característico tom áspero em cartas enviadas para o historiador português João Lúcio de Azevedo. No entanto, foram essas correções e todas as orientações de Capistrano que ajudaram Taunay a seguir os rumos sugeridos por ele em 1902.

Afonso de Taunay considerava que o objetivo principal de seu trabalho era a "reconstituição" do passado brasileiro. Após a conferência realizada em 1911 para a abertura do curso de História Universal na Faculdade Livre de Filosofia e Letras de São Bento, Taunay começou a se definir como historiador. A linguagem empregada por ele nas conferências e textos apresentados no decorrer desse capítulo remete ao principal tema que ele pesquisou, ou seja, a história das Bandeiras.

\footnotetext{
${ }^{113}$ TAUNAY, Afonso de E. J. Capistrano de Abreu. In memorian. Anais do Museu Paulista. Tomo terceiro, 1927, p. XVII.

${ }^{114}$ Ibidem , p. XVIII.

${ }^{115}$ TAUNAY, Afonso de E. J. Capistrano de Abreu. In memorian ..., op. cit., p. XIII.
} 
Taunay descreveu-se, muitas vezes, como "bandeirante", "desbravador", "homem destemido" diante das "buscas da verdade" nas "minas escondidas do passado".

A partir dos textos apresentados até aqui, pode-se afirmar que, como um "mosaísta" que reúne as peças dispersas nos documentos produzidos no passado e descobertos no presente, Taunay acreditava que, como havia aprendido com Capistrano de Abreu, a História devia ser composta por diversas "monografias pormenorizadas" que se detivessem ao pitoresco, à vida comum, aos costumes. Para a composição destes mosaicos da história Taunay divulgou, em suas aulas inaugurais e discursos, que era preciso seguir os procedimentos da crítica externa e interna do documento em busca da verdade moderna. Dessa forma, ele reuniu os ensinamentos adquiridos com os historiadores franceses que resumiu em 1911 e as orientações de Capistrano de Abreu, tornando-se um metódico coerente com as produções brasileiras das primeiras décadas do século XX.

\section{Referências bibliográficas}

ABREU, Capistrano de. Necrológio de Francisco Adolfo de Varnhagen, visconde de Porto Seguro; Sobre o visconde de Porto Seguro. Ensaios e Estudos (Crítica e História). $1^{\text {a }}$ série, $2^{\mathrm{a}}$ ed. Rio de Janeiro: Civilização Brasileira; Brasília: INL, 1975.

ABREU, Capistrano de. Correspondência de Capistrano de Abreu, volume 1; edição organizada e prefaciada por José Honório Rodrigues. $2^{\mathrm{a}}$ ed. Rio de Janeiro: Civilização Brasileira; Brasília: INL, 1977.

ALCÂNTARA, Aureli Alves de. Taunay e a iconografia cafeeira: discurso e recurso. 2000. (Trabalho de conclusão do curso de especialização em Museologia). Museu de Arqueologia e Etnologia - Universidade de São Paulo.

ALVES, Ana Maria de Alencar. O Ipiranga apropriado: ciência, política e poder: o Museu Paulista, 1893-1922. São Paulo: Humanitas/FFLCH/USP, 2001.

AMED, Fernando José. História ao portador: interlocução privada e deslocamento no exercício da escrita de cartas de João Capistrano de Abreu (1853-1927). Dissertação de mestrado, História Social, Faculdade de Filosofia, Letras e Ciências Humanas, Universidade de São Paulo, 2001.

ARAÚJO, Ricardo Benzaquen. Ronda noturna: narrativa crítica e verdade em Capistrano de Abreu. Estudos Históricos. Rio de Janeiro. nº. 1, p. 28-54, 1988.

BLOCH, Marc. Apologia da história ou O ofício do historiador. Rio de Janeiro: Jorge Zahar ed., 2001.

BOURDÉ, Guy; MARTIN, Hervé. A escola metódica. In: As escolas históricas. Portugal: Publicações Europa-América, 1983.

BREFE, Ana Cláudia Fonseca. Museu Paulista: Affonso de Taunay e a memória nacional, 1917-1945. São Paulo: Unesp/Museu Paulista, 2005. 
CANABRAVA, Alice. Apontamentos sobre Varnhagen e Capistrano de Abreu. Revista de História. São Paulo, USP, 18 (88), out/dez, 1971.

D`ALESSIO, Márcia Mansor. Práticas historiográficas: um estudo. In: MALATIAN, Teresa; LEME, Marisa Saenz; MANOEL, Ivan Aparecido (orgs.). As múltiplas dimensões da política e da narrativa. Franca, São Paulo: Unesp, 2003.

DIEHL, Astor Antônio. O que é História? Sistemas de referência e narrativa. Capistrano de Abreu e o moderno sentido para a historiografia brasileira. Ágora. Santa Cruz do Sul, v. 11, nº 1, p. 49-77, jan./ jun. 2005.

DIEHL, Astor Antônio. A cultura historiográfica brasileira: do IHGB aos anos 1930. Passo Fundo: Ediupf, 1998.

DOSSE, François. A história à prova do tempo: da história em migalhas ao resgate do sentido. São Paulo: Editora Unesp, 2001.

ELIAS, Maria José. Museu Paulista: memória e história. Tese de doutorado, História, Faculdade de Filosofia, Letras e Ciências Humanas, Universidade de São Paulo, 1996.

FEBVRE, Lucien. Combates pela História. $3^{\text {a }}$ ed. Lisboa: Editorial Presença, 1989.

FERREIRA, Antônio Celso. A epopeia bandeirante: letrados, instituições, invenção histórica (1870-1940). São Paulo: Unesp, 2002.

GOMES, Ângela de Castro (organização, introdução e notas). Em família: a correspondência de Oliveira Lima e Gilberto Freyre. Campinas, São Paulo: Mercado de Letras, 2005 (Coleção Letras em Série).

GONTIJO, Rebeca. História e historiografia nas cartas de Capistrano de Abreu. História (São Paulo), v. 24, p. 159-185, 2005.

GONTIJO, Rebeca. O intelectual como símbolo da brasilidade: o caso Capistrano de Abreu. In: ABREU, Martha; SOIHET, Rachel; GONTIJO, Rebeca (org.). Cultura política e leituras do passado: historiografia e ensino de história. Rio de Janeiro: Civilização Brasileira, 2007, p. 309-327.

GUIMARÃES, Manoel Luiz Salgado. Entre amadorismo e profissionalismo: as tensões da prática histórica no século XIX. Topoi, Rio de Janeiro, dezembro de 2002, p. 184-200.

HARTOG, François. O século XIX e a história: o caso Fustel de Coulanges. Rio de Janeiro: Editora UFRJ, 2003.

HARTOG, François. Michelet, a história e a "verdadeira vida". Ágora. Santa Cruz do Sul, v. 11, no 1, jan./ jun. 2005, p. 13-20.

IGGERS, Georg G. Historiografy in the twentieth century: from scientific objectivity to the postmodern challenge. Edition including a new epilogue by the author. Middletown, Connecticut: Wesleyan University Press, 2005.

LANGLOIS, Ch. V.; SEIGNOBOS, Ch. Introdução aos estudos históricos. Tradução Laerte de Almeida Morais. São Paulo: Renascença, 1946. 
LAPA, José Roberto do Amaral. A história em questão: Historiografia brasileira contemporânea. Petrópolis, Rio de Janeiro: Vozes, 1976.

LOFEGO, Silvio Luiz. IV Centenário da cidade de São Paulo: uma cidade entre o passado e o futuro. São Paulo: Annablume, 2004.

MAKINO, Myoko. A construção da identidade nacional: Afonso de E. Taunay e a decoração do Museu Paulista (1917-1937). Tese de doutorado, História, Faculdade de Filosofia, Letras e Ciências Humanas, Unversidade de São Paulo, 2003.

MATTOS, Cláudia Valladão de. Da palavra à imagem: sobre o programa decorativo de Affonso Taunay para o Museu Paulista. Anais do Museu Paulista. São Paulo, v. $6 / 7, n^{\circ} 7,2003$, p. 123-148.

MATOS, Odilon Nogueira. Afonso de Taunay historiador de São Paulo e do Brasil: perfil biográfico e ensaio bibliográfico. São Paulo: Museu Paulista, 1977.

MESGRAVIS, Laima. Afonso de Escragnolle Taunay, o historiador de São Paulo. In: TAUNAY, Afonso de E. São Paulo nos primeiros anos: ensaio de reconstituição social; São Paulo no século XVI: história da vila piratiningana. São Paulo: Paz e Terra, 2003.

NAGLE, Jorge. Educação e sociedade na Primeira República. $2^{\mathrm{a}}$ ed. Rio de Janeiro: DP\&A, 2001.

OLIVEIRA, Cecília Helena de Salles. Museu Paulista: espaço de evocação do passado e reflexão sobre a história. Anais do Museu Paulista: História e cultura material. Nova série, vol. 10/11, 2002-2003, p. 105-126.

OLIVEIRA, Gilberto Habib. O espólio Bernardelli no Museu Paulista e o pensamento museológico de Affonso de Escragnolle Taunay: estudos teóricometodológicos em Museologia e a historicidade do fenômeno museal. 2000. (Trabalho de conclusão do curso de especialização em Museologia). Museu de Arqueologia e Etnologia - Universidade de São Paulo.

OLIVEIRA, Maria da Glória. Crítica, método e escrita da história em João Capistrano de Abreu (1853-1927). Dissertação de mestrado, História, Programa de PósGraduação em História da Universidade Federal do Rio Grande do Sul, 2006.

PEREIRA, Daniel Mesquita. Descobrimentos de Capistrano. A história do Brasil "a grandes traços e largas malhas". Tese de doutorado, História, Programa de Pós-Graduação em História Social da Cultura, Pontifícia Universidade Católica do Rio de Janeiro, 2002.

PONS, Anaclet e SERNA, Justo. Apologia de la história metódica. Pasajes. Revista de pensamiento contemporâneo. Valência, Espanha, $n^{\circ}$ 16, invierno de 2005, p. $128-136$.

PROST, Antoine. Charles Seignobos revisité. Vingtième Siècle. Revue d'histoire. Paris, $n^{\circ}$ 43, jul./set. 1994, p. 100-118.

REIS, José Carlos. As identidades do Brasil: de Varnhagen a FHC. $3^{\mathrm{a}}$ ed. Rio de 
Janeiro: Editora FGV, 2000.

RODRIGUES, José Honório. História e historiadores do Brasil. São Paulo: Fulgor, 1965.

RODRIGUES, José Honório. História e historiografia. Petrópolis, Rio de Janeiro: Editora Vozes, 1970.

SEVCENKO, Nicolau. Orfeu extático na metrópole: São Paulo, sociedade e cultura nos frementes anos 20. São Paulo: Companhia das Letras, 1992.

TAUNAY, Afonso de E. Os princípios gerais da moderna crítica histórica. RIHGSP, v. XVI, 1914, p. 323-344.

TAUNAY, Afonso de E. Um grande bandeirante: Bartolomeu Paes de Abreu (1674 - 1738). Exploração do Paraná, do Rio Grande do Sul e de Mato Grosso; a conquista de Goiás. Anais do Museu Paulista. tomo I, 1922.

TAUNAY, Afonso de E. História geral das Bandeiras paulistas: escrita à vista de avultada documentação inédita dos arquivos brasileiros, espanhóis e portugueses. Tomo terceiro (1641-1651). São Paulo: Tipografia Ideal/H. L. Canton, 1927.

TAUNAY, Afonso de E. História antiga da abadia de São Paulo (1598-1772). São Paulo: Tipografia Ideal/Heitor L. Canton, 1927.

TAUNAY, Afonso de E. J. Capistrano de Abreu. In: Memorian. Anais do Museu Paulista. tomo terceiro, 1927.

TAUNAY, Afonso de E. Antonil e sua obra. Estudo biobibliográfico. In: ANTONIL, André João. Cultura e opulência no Brasil. $2^{\mathrm{a}}$ ed. São Paulo: Melhoramentos; Brasília: INL, 1976.

TAUNAY, Afonso de E. Relatos monçoeiros. Belo Horizonte: Ed. Itatiaia; São Paulo: Ed. da Universidade de São Paulo, 1981.

TAUNAY, Afonso de E. História da cidade de São Paulo. Brasília: Senado Federal, Conselho Editorial, 2004.

TEIXEIRA. Anísio. A universidade de ontem e de hoje. Revista Brasileira de Estudos Pedagógicos. Rio de Janeiro, v. 42, n. 95, jul./set. 1964, p. 27-47.

TEIXEIRA. Anísio. Uma perspectiva da educação superior no Brasil. Revista Brasileira de Estudos Pedagógicos. Brasília. v. 50, nº 111, jul./set. 1968, p. 21-82.

WEHLING, Arno. Fundamentos e virtualidades da epistemologia da história: algumas questões. Estudos Históricos. Rio de Janeiro, vol. 5, nº 10, 1992.

WEHLING, Arno. Ainvenção da História: estudos sobre o historicismo. Rio de Janeiro: Editora Central da Universidade Gama Filho; Niterói: Editora da UFF, 1994.

WEHLING, Arno. Estado, história, memória: Varnhagen e a construção da identidade nacional. Rio de Janeiro: Nova Fronteira, 1999. 